\title{
Construing the ecological perspective of the Tai Dam as seen in 'Sen Huen' ritual manuscripts
}

Pattama Patpong

Correspondence: ppattama@yahoo.com; pattama.pat@mahidol.ac.th Research Institute for Languages and Cultures of Asia, Mahidol University, 999 Phuttamonthon 4 Road, Salaya, Nakhon Pathom 73170, Thailand

\begin{abstract}
This paper is a part of the research project entitled 'Transmission of 'Sen Huen' ritual as an intangible cultural heritage of Tai Dam ethnic group". The Sen Huen ritual is a significant aspect of the Tai Dam's ancestor worship. This ritual has to be conducted in a room set for ancestral spirits called kallo4ho: $\eta 3$ and the ritual is required to be done every $2-3$ years to avoid bad luck and receive good fortune and blessings, otherwise the descendants will suffer misfortunes such as illness, hardship and adversity. The theoretical framework applied to this study is Systemic Functional Linguistics, in particular the description of the system of transitivity, which is part of the ideational metafunction. The paper aims to investigate how the Tai Dam perception of local ecology is construed grammatically in the transitivity system. The system of transitivity is a resource for construing human experience of change or goings - on in the flow of events inside and around us. A quantum of change in the flow of events is construed as a configuration of a process involving one or more participants and attendant circumstances. The data were drawn from six Sen Huen ritual manuscripts which were collected from six Sen Huen ritual shamans residing in four provinces of Thailand: Phetchaburi, Ratchaburi, Nakhon Pathom, and Suphanburi provinces. The study reveals that there is a connection between the process and circumstance configurations expressing the Tai Dam ecological perspective. It illustrates a clear correlation between the semiotic model of time (month by month) and space (geographical space) that is construed by language and the material actions that are carried out by different participants (both human and non-human).
\end{abstract}

Keywords: Tai Dam (Thai Song Dam) ethnic group, Sen Huen ritual manuscripts, Ancestor worship, The transitivity system, Process, Participant, Circumstance

\section{Introduction}

Tai $\mathrm{Dam}^{1}$ are Tai-speaking people. It is believed that their original homeland was Son La, Dien Bien Phu, Vietnam. The Tai Dam have also settled in Nghia Lo, Yen Bai. Both settlements are located in the heart of the Sip Song Chu Tai between the Red and Black rivers in northern Vietnam (Lebar et al. 1964: 220). Yimrewat (2001: 7-8) suggests that Sip Song Chu Tai means "the twelve lands of the Tai" (Sip Song means 'twelve', Chu is derived from the Vietnamese word Châu meaning 'area', and Tai refers to the Tai).

Trong, a well-knownTai Dam scholar, (2007) wrote a book entitled "The Thái: Ethnic Community in Vietnam". He reports various aspects of Tai Dam

(c) 2016 The Author(s). Open Access This article is distributed under the terms of the Creative Commons Attribution 4.0 International License (http://creativecommons.org/licenses/by/4.0/), which permits unrestricted use, distribution, and reproduction in any medium, provided you give appropriate credit to the original author(s) and the source, provide a link to the Creative Commons license, and indicate if changes were made. 
living in Vietnam including traditional and modern agricultural activities (pp. 1-15). Lebar et al. (1964): 221-222) described Tai Dam's economic activities including features of cultivation, fishing and hunting skills. The Tai Dam residing in Vietnam rely on an agricultural culture with occasional hunting-gathering ${ }^{2}$.

The Tai Dam are predominantly wet-rice cultivators. They live in mountain valleys. Some Tai Dam also cultivate upland rice on the slopes using the swidden method. Once cultivated, the fields are abandoned after three years to lie fallow for eight to ten years before being recultivated. Buffalo are used as draft animals. The Tai Dam are good hunters and fishermen using hunting weapons such as crossbows and traps. Hunting and fishing activities provide necessary supplementary food, in addition to which the Tai Dam gather vegetables including bamboo shoots gathered in the forest (Lebar et al. 1964; Trong, 2007).

In Thailand, the Tai Dam are an ethnic group residing in the western region of Thailand (Burusphat et al., 2011). Their ancestors migrated from Muang Thaeng (or Dien Bien Phu located in northwestern Vietnam). Written evidence indicates that the Tai Dam were captured and relocated to Thailand as prisoners of war a total of six times from the late $18^{\text {th }}$ to $19^{\text {th }}$ century (see Yensamut, 1981: 25-30; Buranasing, 1988: 15-18; Dechapratumwan, 2015: 16-17 for further details of the six settlements). The first Tai Dam migrants settled in Phetchaburi province in 1779 during the reign of King Taksin of Thonburi. At later stages, Tai Dam moved to nearby provinces including Ratchaburi, Suphanburi, Nakhon Pathom, Samut Songkhram, Samut Sakhon, and Kanchanaburi provinces in the western region. They are found in Loei province in the northeast as well as, Pichit, Phitsanulok, and Sukhothai provinces in the lower northern region, Nakhonsawan, Saraburi, Lopburi provinces in the central region and Chumporn and Suratthani provinces in the south (Udomwej, 2004; Burusphat et al., 2011).

This paper reports on a preliminary exploration of the transitivity system of a particular registerial domain, namely domestic procedural texts; to be precise 'domestic ritual procedural texts' (cf. Martin and Rose, 2008). These particular texts are seen as an influential discourse in Tai Dam community. The domestic ritual procedural texts investigated are ancestor worship or Sen Huen ritual manuscripts. These Sen Huen ritual manuscripts record many aspects of Tai Dam's way of life and beliefs.

Tai Dam people residing in the western region of Thailand practice a number of rituals that are transmitted from generation to generation (Burusphat et al., 2011). One of these significant rituals is the Sen Huen ritual. Tai Dam people have a strong belief that the ancestor worship or 'Sen Huen' ritual is the key ritual conducted for patrilineal ancestors ( $s e: n 1^{3}$ means offer or sacrifice whereas hman2, as pronounced in Tai Dam phonological system, means house or household). The persons who are worshipped are ancestral spirits. Based on Tai Dam's social classes, there are two groups of Tai Dam people: aristocratic surname group (or phu5 taw5) and commoner surname group (or phu5 no:j6) (cf. Aroonkit, 1987: 23, Phosan, 2009: 294). Each group has its own ancestor worship practices. Therefore, the Sen Huen ritual manuscripts involve a spiritual procedure and an interaction between the Sen Huen ritual shaman and the ancestral spirits. They are chanted by shamans during the Sen Huen ritual, which lasts 7-8 hours depending on numbers of ancestral names written on the genealogical book 
called pap3phi:1hman2. The ancestral names are called by the shamans during the process of making offerings to the ancestral spirits.

The paper draws on Systemic Functional Linguistics to investigate how the Tai Dam perception of natural perspective, as it is manifested in Sen Huen ritual manuscripts, is construed grammatically by means of the transitivity system.

\section{Previous researches}

Previous studies on Tai Dam have focused on both the anthropological and linguistic fields. In anthropological oriented research, most studies have been concerned with Tai Dam's way of life, social structure, and rituals; there have been studies under the scope of sociology (Aroonkit, 1986, 1987; Wadkeaw, 1978; Muanjancheoy, 1999) and cultural studies (Pittphat 1978, 2002; Janthasoon, 1995; Kongyimlamai, 2003; Panalai, 2008). In linguistic oriented research, many studies have focused on various aspects of the linguistic system but also on the language in its socio-cultural environment: phonological systems (Anantrawan, 1978; Decha, 1987; Maneewong, 1987), phonological variation (Wattanaprasert \& Liamprawat, 1988; Thavorn 2013; Yooyen, 2013), morphological systems (Yensamut, 1981; Buranasing, 1988), grammatical systems (Panich 1994; Jiranuntanaporn et. al., 2003), sociolinguistic research (Dechapratumwan, 2015), and folklore (Subsook et al. 1980; Klinubon, 2009). Discourse studies on Tai Dam include work on phonological strategies in Tai Dam poetic discourse by Hartmann (1994), and work on participant reference in narrative discourse by Edwards (2011). Recent Tai Dam discourse studies in Thailand have concentrated on narrative discourse, folktales and Generic Structure Potential, and thematic progression of folktales (Patpong 2010, 2011a, 2011b, 2013), but rather less attention has been paid to procedural discourse. There has been only one study of Tai Dam ritual procedural discourse, viz. Osiri (2013). However, it was focused on procedural discourse of various rituals retold step by step by ritual shamans. After reviewing a number of existing studies on the Tai Dam, it appears there remains a need for a study on Tai Dam ritual procedural discourse focusing on ritual manuscripts.

\section{SFL as a resource in describing language in Thailand}

Thailand is situated at the central Southeast Asian region. It is a country which represents one of the world's most complex patterns of linguistic, cultural and ethnic diversity (Premsrirat et al., 2004). Thailand represents a complex area of language diversity-one of linguistic challenge in the region and is home to more than 67 million people speaking approximately 70 minority languages (Premsrirat et al., 2004; Premsrirat, 2007). As reported by Premsrirat (2007), at least fourteen minority languages are now endangered and facing difficulty in surviving to the end of this century.

Systemic Functional Linguistics has been developed to be a general linguistic resource that is powerful and flexible enough to address a wide range of questions about language. Systemic Functional Linguistics has been applied to areas as different as: multilingual studies and language typology, language descriptions (exploring 
metafunction and stratification dimensions), translation studies, language development, educational linguistics, computational linguistics, stylistics and the study of verbal art, clinical linguistics, forensic linguistics, and multimodality (Halliday, 1985; Caffarel, Martin \& Matthiessen, 2004). In the $21^{\text {st }}$ century, there is great demand around the world for comprehensive systemic functional descriptions of different languages (Halliday \& Matthiessen, 2004; Matthiessen \& Halliday, 1997; Matthiessen, 1995; Martin 1992; Thompson, 1996/2004) to support a range of activities in research and applications, including work involving discourse analysis, translation studies and typology studies. A recent contribution to functional language descriptions and typological research was a conference on functional language typology organized by the Martin Centre for Appliable Linguistics, Shanghai Jiao Tong University in 2015. In the Thai context, comprehensive descriptions of endangered and ethnic languages will benefit, and be of interest to, not only those speech communities whose languages have been described in systemic functional interpretation, but also the linguists of various other sub-disciplines, including sociolinguistics and language planning, anthropological linguistics. Given this urgent need, language documentation is a fundamental starting point.

Systemic Functional Linguistics is the key approach applied to endangered and ethnic language descriptions. In relation to Systemic Functional Linguistics, the notion of social accountability is a great motivator behind proposals for the development of language descriptions as resources for ethnic communities. Social accountability has been emphasized in Systemic Functional Linguistics. It is mentioned in several contexts in the relevant literature (Halliday, 1984, 1985; Matthiessen and Nesbitt, 1996). Matthiessen and Nesbitt (1996: 59) state that Systemic functional linguistic theory is itself interpreted as a semiotic resource for modelling and describing language. Therefore, investigating and describing ethnic and endangered languages with a view to sustaining them as resources for their communities and resources for prolonging the life of the speech communities is urgently needed. Systemic Functional Linguistics contributes to the sustainability of ethic and endangered language research in Thailand.

\section{The Sen Huen ritual manuscript and text selection}

In this study, the data were drawn from six Sen Huen ritual manuscripts taken from six Sen Huen ritual shamans who reside in four provinces located in the western region of Thailand: Phetchaburi, Ratchaburi, Nakhon Pathom, and Suphanburi provinces.

It is believed that the Sen Huen ritual manuscripts transmitted to Tai Dam descendants residing in Thailand originate from Vietnam which is their original homeland (Chavalit Arayayutitham ${ }^{4}$, interviewed, July 26, 2014). The Sen Huen ritual manuscript comes out of an oral tradition in which the manuscript was transmitted to subsequent generations by memory. Originally, the Sen Huen ritual manuscript was written in the Tai Dam script. It was transmitted from one shaman generation to the next. It has local variants, but the original chapters of each version are the same (Figs. 1 and 2).

Figure 3 is a photo of Mr. Pheng Phetyuan's Sen Huen ritual manuscript typed in Tai Dam fonts and printed in the form of an A4 size book. Chavalit 


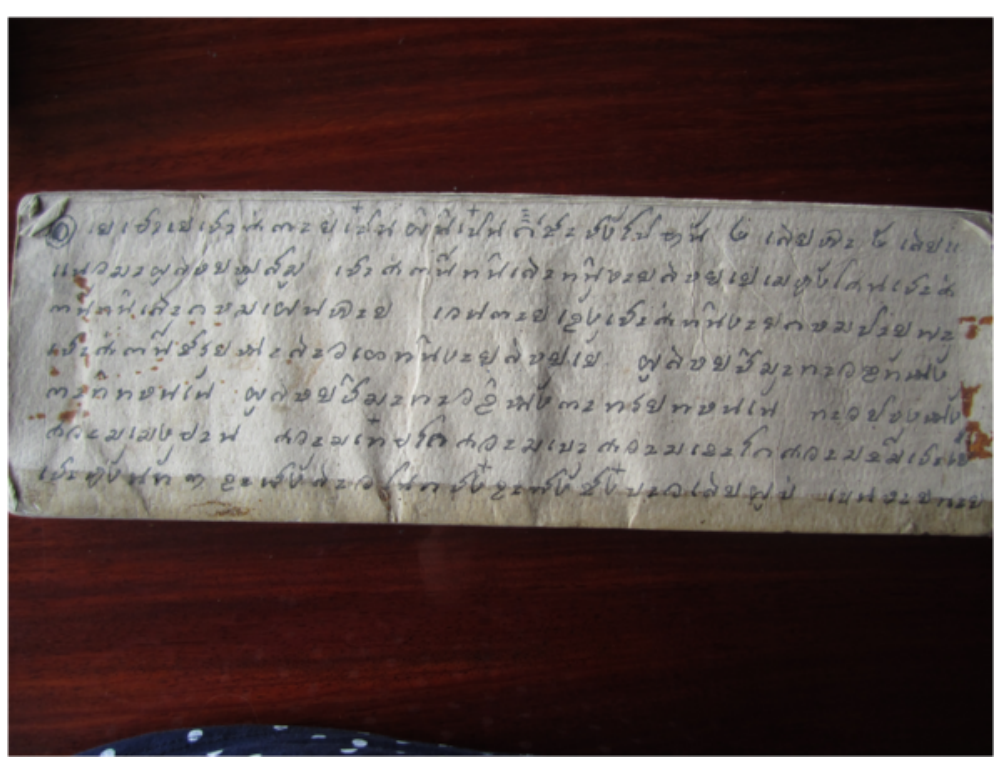

Fig. 1 Tai Dam script (a funeral manuscript) written on A3 paper and bound as a palm leaf manuscript (Source: Chavalit Arayayutitham)

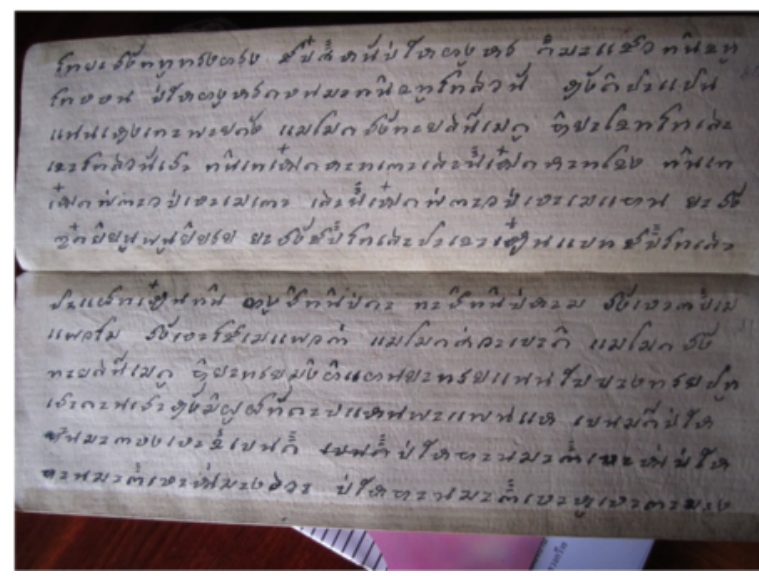

Fig. 2 Two pages of Tai Dam script (a funeral manuscript) written on A3 paper and bound as a palm leaf manuscript (Source: Chavalit Arayayutitham)
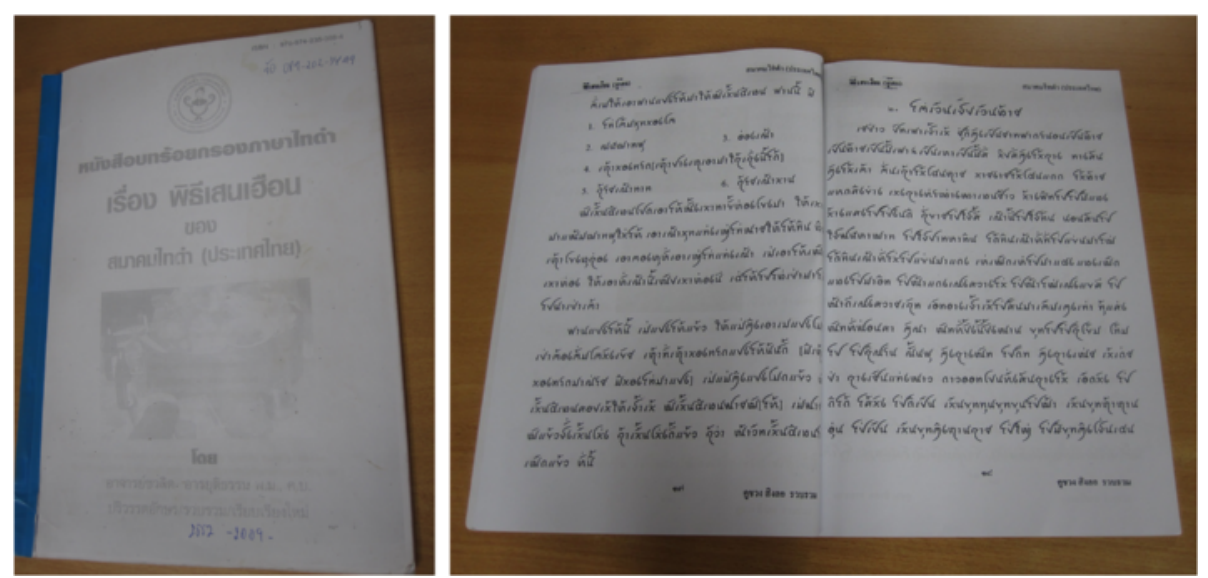

Fig. 3 Mr. Pheng Phetyuan's Sen Huen ritual manuscript typed and printed on A4 paper (Source: Chavalit Arayayutitham, 2009) 
Arayayutitham (interviewed, July 26, 2014) said that the original manuscript was copied and written in Tai Dam script by his father (Mr. Yu Thinbangbon). It is more than one hundred years old. Later, Mr. Chavalit Arayayutitham reproduced it with computer-based Tai Dam fonts to be used in reading and writing Tai Dam classes taught by him and his retired colleagues (Mr. Suree Thongkhonghan, the former president of the Tai Dam Association (Thailand)). This Sen Huen ritual manuscript is Text 4, presented in Table 1.

The Sen Huen ritual manuscript serves an important social function. Traditionally, it is recited by a shaman during the Sen Huen ritual. The Sen Huen ritual is concerned with maintenance of the institutionalized system of Tai Dam belief in ancestral spirits. Its purpose is for use in making offerings to the Tai Dam ancestral spirits. It focuses on task-orientation (i.e., the ancestor worship). The Sen Huen ritual manuscript is composed of many chapters (called co?l).

In order to get a sense of the Sen Huen ritual manuscript, synopses of some relevant chapters, which are arranged by content, are provided as follows:

- Introductory chapter: the shaman informs the ancestral spirits why the 'Sen Huan' ritual is taking place on this auspicious day mma6wen2ton1. The head of the family is sick (caw5sua5 caw5se:n1). He is also known as Sen Huen host. There is no means to cure his sickness. In addition, whatever activity he does, it seems unsuccessful (e.g., dyeing, farming, weaving, and raising of domesticated animals). He also narrates preparing the Sen Huen items to be offered. (e.g., raising a male pig and brewing homemade liquor).

- Ancestral Calling chapter: The shaman calls ancestral spirits from various places to come down from 'sky' city (heaven) to take the offerings. He talks about the dwellings of each ancestral spirit and mentions his duties.

- Raw pig sacrificing I, II, III chapters: The shaman informs and chants to the (good) ancestral spirits to take the first, second and third round of raw pig offering. Those ancestral spirits died in a normal way.

- Liquor offering I, II, III chapters: The shaman informs and chants to the (good) ancestral spirits to take the first, second and third round of liquor offering. Those ancestral spirits died in a normal way.

- Collective sacrificing chapter: The shaman informs and chants to other ancestral spirits who died in a bad way and condition (killed, had an accident, or died when they were young) to take the raw pig and liquor offerings. This collective sacrificing chapter is chanted after each raw pig sacrificing chapter and liquor offering chapter.

- Sacrificing talisman item chapter: The shaman informs and chants to the talisman items to take the offerings (e.g., Tai Dam's life symbol known as taj5, witch, cloth, ghost, and light).

- Ancestral Sending off chapter: The shaman chants to all ancestral spirits to send them off to return to the 'sky' (heaven).

- Blessing chapter: This is a complementary chapter to the introductory chapter. All obstructions have been lifted and life becomes unproblematic and prosperous. The shaman asks the ancestral spirit to bless the Sen Huen host (or head of the family) and his family members. 
There are two types of Sen Huen ritual: the Sen Huen ritual of the aristocratic surname group (se:n1 hman2 phu5 taw5) and the Sen Huen ritual of the commoner surname group (se:n1 hman2 phu5 no:j6). In the Sen Huen rituals, shamans are the key persons. Their status and roles are related to the transmission of this particularly cultural heritage. They are seen and respected by the Sen Huen host, his/her family members, and the Tai Dam community as representatives of the Sen Huen hosts, ritual leaders, cultural transmitters, cultural service providers, cultural coordinators linking relationship between the Sen Huen host, family members and community, and the local community's wise men. In the Sen Huen rituals, the shamans are mediators as they are able to act as mediums between the human and spirit worlds (Schliesinger, 2001: 117).

Panalai (2008) states that transmission processes of the Sen Huen ritual through the shamans are conducted through two channels: direct transmission and indirect transmission.

The direct transmission is done via oral indoctrination and on-the-job training. The indirect transmission is passed on to the next shaman generation as well as the general public through oral explanation and participant observation (Janthasoon, 1995; Panalai, 2008).

The teaching and learning method is based on a one-to-one learning process through an oral tradition of memorizing chapters and practicing chanting with Tai Dam pronunciation. Shaman apprentices visit the mentor's house and copy the Sen Huen ritual manuscript chapter by chapter with a script of their choice. Some copy and write in the Tai Dam script, but many of them prefer to copy and write in the Thai script, as they do not know how to write the Tai Dam script. When they chant the chapters, they have to chant using Tai Dam pronunciation. The shaman apprentices read and memorize all the copied chapters; they practice and read them aloud. They may ask their mentors to assess their memorization and Tai Dam pronunciation.

In the training process, shaman apprentices will accompany their mentors to different ritual functions in order to observe, assist, and practice their skills. These activities are done under the supervision of the mentors who will monitor and assess the apprentices' progress.

During the training process, the shaman apprentices learn Tai Dam beliefs, customs, and ritual wisdom. The accompaniment of the mentors to observe the Sen Huen ritual and practice of some chapters are two key elements of transmission as they are processes for integrating theory and (i.e., learning the Sen Huen ritual manuscripts, memorizing, and practicing chanting each chapter out loud) and practice (i.e., assisting the mentors to conduct some chapters during the course of the Sen Huen ritual). These two processes enhance the transmission process.

In this study, one part of the Sen Huen ritual manuscripts is investigated, namely, ?a:n3pi:1buan1 which literally means 'yearly and monthly reading' and can be translated as the readings of annual and monthly cycles. In the readings, they are concerned with various activities taking place in the Tai Dam commuities. These activities include agriculture, social aspects, and ritual 
activities unfolding through time, month by month. The six Sen Huen ritual manuscripts used in this current study were glossed and translated into Thai by Mr. Chavalit Arayayutitham. The readings of annual and monthly cycles are only found in the Sen Huen ritual manuscripts of the commoner surname group (Phu Noi manuscripts). The Sen Huen ritual practices of the Phu Noi commoner surname group involve various procedures which are different from the practices of the Phu Tao aristocratic surname group (Aroonkit, 1987: 23, Phosan, 2009: 294). In addition, Phu Noi manuscripts are composed of more chapters (co?l) than are Phu Tao manuscripts. Key chapters on food and liquor offerings are found in both Phu Noi and Phu Tao manuscripts. However, chapters concerned with shaman invitation, pig and liquor preparation, yearly and monthly reading, and announcement of Sen Huen ritual to other family members are not found in Phu Tao manuscripts. Much attention on providing details on how a Sen Huen ritual is arranged and conducted is found mainly in the Phu Noi manuscripts.

During the course of the Sen Huen ritual, after the Sen Huen ritual shaman has chanted the blessing messages to bless the Sen Huen host and the host's family members (kamltu:1kaml), the host's relatives (kaml tu:1kamlhman2no:k4) and the host's household (tw:1kam1hman2), as representatives of the Sen Huen host, the shaman will read the annual and monthly cycle message to the ancestral spirits. The readings are chanted from the first month (i.e., December) to the last month (i.e., November) to complete the cycle of the whole year ${ }^{5}$.

The reading mentions about the weather, local ecology, and activities conducted by the Tai Dam people year-round. The readings of annual and monthly cycles taken from six Sen Huen ritual manuscripts were composed of 542 complex clauses and 1,238 simple clauses (as shown in Table 1). Example 1 shows an instance of one clause complex which is composed of three simple clauses.

Table 1 shows information about the six versions of the Phu Noi manuscripts taken from six shamans and their residencies. Each manuscript is segmented first into complex clauses and then into simple clauses. As this paper is concerned with the

Example (1): Text 6

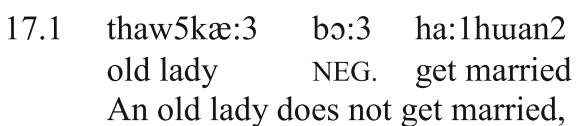

17.2 la:n2 $(\varnothing=$ saw2 $) \quad$ ha:1 huan2

CONJ.: if (she) get married

if (she) gets married,

$17.3(\varnothing=$ saw2) la:n2ha:n6

(she) get devoiced

(she) will get devoiced. 
Table 1 Number of complex clauses and simple clauses of the six selected manuscripts

\begin{tabular}{lllll}
\hline Text & Shaman (source) & Residence location & Complex clauses & Simple clauses \\
\hline 1 & $\begin{array}{l}\text { Mr. Suwan } \\
\text { Dindaeng }\end{array}$ & $\begin{array}{l}\text { Huaythachang Sub-district, Thayang District, } \\
\text { Phetchaburi province }\end{array}$ & 88 & 202 \\
2 & $\begin{array}{l}\text { Mr. Sombun } \\
\text { Thongrop }\end{array}$ & $\begin{array}{l}\text { Donkha Sub-district, Bangphae District, } \\
\text { Ratchaburi province }\end{array}$ & 86 & 194 \\
$3 \quad \begin{array}{l}\text { Mr. Samruay } \\
\text { Canphong }\end{array}$ & $\begin{array}{l}\text { Huayyangthon Sub-district, Pak Thow District, } \\
\text { Ratchaburi province }\end{array}$ & 86 & 226 \\
$4 \quad \begin{array}{l}\text { Mr. Chavalit } \\
\text { Arayayutitham }\end{array}$ & $\begin{array}{l}\text { Donkhamin Sub-district, Kamphansseng District, } \\
\text { Naknon Pathom province }\end{array}$ & 95 & 210 \\
5 & $\begin{array}{l}\text { Mr. Tham } \\
\text { Rotcharuengphan }\end{array}$ & $\begin{array}{l}\text { Phaihuchang Sub-district, Banglen District, } \\
\text { Naknon Pathom province }\end{array}$ & 86 & 183 \\
6 & $\begin{array}{l}\text { Mr. Kan Khaisasart } \\
\text { Donmakue Sub-district, Uthong District, } \\
\text { Suphan buri province }\end{array}$ & 101 & 223 \\
& Total & 542 & 1,238 \\
\hline
\end{tabular}

experiential mode of the ideational metafunction, all simple clauses are analysed grammatically in terms of the system of TRANSITIVITY.

\section{The experiential clause grammar: the system of TRANSITIVITY}

The ideational metafunction can be divided into two subtypes embodying different modes of construing experience-experiential and logical. Within the simple clause, the experiential metafunction construes experience in terms of configurations such as the configuration of a process, participants involved in it and attendant circumstances by means of the grammatical system of TRANSITIVITY (Halliday and Matthiessen, 1999, Halliday and Matthiessen, 2010). Thompson (2014: 94) states that the term 'transitivity' will probably be familiar as a way of distinguishing between verbs according to whether they have an Object or not (i.e., transitive verbs and intransitive verbs). Here, however, it is being used in a much boarder sense and refers, in particular, to a system for describing the whole clause, rather than just the verb and its Object.

The logical metafunction construes experience as chains, developed out of highly generalized relations such as elaboration, exemplification and modification, and combines clauses into complex clauses by means of the systems of TAXIS and LOGICO-SEMANTIC TYPE (Halliday and Matthiessen, 2004: Chapter 7).

This paper is concerned mainly with the experiential grammar of the clause-an investigation of how the Tai Dam perception of local ecology is construed grammatically through an analysis of the system of TRANSITIVITY, or process type.

The system of TRANSITIVITY embodies two parts: nuclear TRANSITIVITY (i.e., the transitivity of processes and participants) and circumstantial TRANSITIVITY (i.e., the transitivity of circumstances). The characteristics of each configuration are based on Halliday and Matthiessen (2004: Chapter 5) and Matthiessen (1995: Chapter 4). The details are presented below.

A process is characterized by its potential for organizing participants into an experiential configuration. Each process is associated with a particular configuration of participant roles. In the Tai Dam language, the process is organized according to the verbal group structure: that is, the process can be expressed by a verbal group, or a verbal 
group complex. Characteristics of each process type are briefly provided in examples 2-8 and are presented in a block analysis format. All of them are examples of nuclear TRANSITIVITY. Examples of circumstantial TRANSITIVITY are presented in example 9 onwards.

- Material clauses are clauses of happening and doing (usually concrete and tangible actions, activities and events).

Example (2) Text 4: 11.2-11.3

\begin{tabular}{|l|l|l|l|}
\hline $\begin{array}{l}\text { buan1 ji:3 ni:5 buan1 } \\
\text { month two this month }\end{array}$ & $\begin{array}{l}\text { taj1 } \\
\text { the Tai Dam }\end{array}$ & $\begin{array}{l}\text { pam5 } \\
\text { cut down }\end{array}$ & $\begin{array}{l}\text { maj6 } \\
\text { tree }\end{array}$ \\
\hline Circumstance: time & Actor & Process: material: doing & Goal \\
\hline
\end{tabular}

'In the second month, the Tai Dam cut down trees,

\begin{tabular}{|l|l|l|}
\hline $\begin{array}{l}\varnothing=\text { sa3 ma:j1) } \\
\text { (they) }\end{array}$ & bo:3 Ret3 & $\begin{array}{l}\text { huan2 } \\
\text { house }\end{array}$ \\
\hline (Actor) & Process: material: doing & Goal \\
\hline
\end{tabular}

(they) do not build a house.'

- Behavioural clauses are clauses of behaving (bodily activity: watching, crying, and laughing).

Example (3) Text 1: 53.9

\begin{tabular}{|l|l|}
\hline $\begin{array}{l}\text { na:y2 } \\
\text { she }\end{array}$ & $\begin{array}{l}\text { hualsu:3 } \\
\text { laugh }\end{array}$ \\
\hline Behaver & Process: behavioural \\
\hline
\end{tabular}

- Mental clauses are clauses of sensing (seeing, thinking, wanting, feeling).

Example (4) Text 5: 17.4 (material clause) -17.5 (mental clause)

\begin{tabular}{|l|l|l|l|}
\hline $\begin{array}{l}\text { la:y2 } \\
\text { CONJ.: if }\end{array}$ & $\begin{array}{l}\text { thaw5 kæ:3 } \\
\text { old lady }\end{array}$ & $\begin{array}{l}\text { sa:n5 } \\
\text { build }\end{array}$ & $\begin{array}{l}\text { huan2 } \\
\text { house }\end{array}$ \\
\hline Conjunction & Actor & Process: material: doing & Goal \\
\hline
\end{tabular}

'If an old lady builds a house,

\begin{tabular}{|l|l|}
\hline $\begin{array}{l}(\varnothing=\text { saw2 }) \\
\text { (she) }\end{array}$ & $\begin{array}{l}\text { la:n2 hə:y1 } \\
\text { be sad }\end{array}$ \\
\hline Senser & Process: mental: emotion \\
\hline
\end{tabular}

she is sad. 
- Verbal clauses are clauses of saying (saying, talking, speaking, reporting).

Example (5) Text 6: 30.3

\begin{tabular}{|l|l|l|}
\hline $\begin{array}{l}\text { sa:w1 } \\
\text { lady }\end{array}$ & $\begin{array}{l}\text { ku:3wa:y2 } \\
\text { call }\end{array}$ & $\begin{array}{l}\text { phua1 } \\
\text { husband }\end{array}$ \\
\hline Sayer & Process: verbal & Receiver \\
\hline
\end{tabular}

'A lady calls her husband.'

- Relational clauses are clauses of being, having, being at (in, on ect.).

They construe being and do this in two different modes: attribution and identification.

(i) Attributive relational clause

Example (6) Text 4: 41.3

\begin{tabular}{|l|l|}
\hline $\begin{array}{l}\text { lan1 (ka21tu:3) } \\
\text { backs (toads) }\end{array}$ & $\begin{array}{l}\text { ja:1 } \\
\text { be rough }\end{array}$ \\
\hline Carrier & Process: attributive relational/Attribute \\
\hline
\end{tabular}

... the backs (of toads) are rough.

(ii) Identifying relational clause

Example (7) Text 5: 20

\begin{tabular}{|l|l|l|l|}
\hline $\begin{array}{l}\text { buan1 sa:m1 } \\
\text { month three }\end{array}$ & $\begin{array}{l}\text { pen1 } \\
\text { be }\end{array}$ & $\begin{array}{l}\text { buan1 di:1lam3 taw5 di:1la:j1 } \\
\text { month be good } \\
\text { more a lot }\end{array}$ \\
\hline Token & Process: identifying relational & Value & \\
\hline
\end{tabular}

The third month is a very good month.

- Existential clauses are clauses of existing (e.g., mi:2 'exist/have')

Example (8) Blessing chapter: 41.1

\begin{tabular}{|c|c|c|c|c|}
\hline $\begin{array}{l}\text { mi:2 } \\
\text { exist/have }\end{array}$ & & $\begin{array}{l}\text { kaw5sip3 } \\
\text { ninety }\end{array}$ & $\begin{array}{l}\text { thə:k3 } \\
\text { CL. }\end{array}$ & $\begin{array}{l}\text { to:1 kwa:j1 } \\
\text { buffalo }\end{array}$ \\
\hline Process: existential & \multicolumn{4}{|c|}{ Exister } \\
\hline
\end{tabular}

'There were 90 buffalos.'

Participants are inherent in a process, being directly involved in it. They are construed as taking part in processes in different ways according to the nature of the process: they may act out the process, they may sense through it, they may say it, they may have some properties related to it, and so on. In the clausal structure, there may be one, two or three participants, depending on the nature of the process. 
Like participants, circumstances are elements of transitivity configured with the process, but they are typically only indirectly involved in the process-attendant on it, and are not inherent in it. They specify a number of semantic relationships of the process-temporal or spatial location, extent in time and space (i.e. duration and distance), cause, reason, manner, and accompaniment.

In terms of its structural realization in the clause, the system of transitivity is realized by a configuration of process + participants + circumstances. Nuclear transitivity will be explored first (Nuclear transitivity profile of the readings of annual and monthly cycles: process and participants section). It is followed by an analysis of circumstantial transitivity (Circumstantial transitivity profile of readings of annual and monthly cycles: process type and circumstantiation section).

\section{Construing the flow of local ecology of the readings of annual and monthly cycles}

In this section, the two parts of the system of transitivity will be discussed: nuclear and circumstantial transitivity.

\section{Nuclear transitivity profile of the readings of annual and monthly cycles: process and participants}

Nuclear transitivity is concerned with the construal of the process and the participants involved in it. The frequency of processes construed in the readings of annual and monthly cycles is presented in Table 2 .

Table 2 below shows the relative frequencies of the selections of the five process types. It provides a statistical profile of the frequency of instantiation constituting these particular texts-readings of annual and monthly cycles.

As Table 2 shows, the most frequent selection in PROCESS TYPE is 'material' at around $82.55 \%$ (the clause grammar of happening and doing). The next process type in terms of frequency is 'relational' at around $9.61 \%$ (the clause grammar of being and having). Mental process is selected next in terms of frequency at around $5.74 \%$ (the clause grammar of sensing). This is followed by behavioural process at around $1.21 \%$ (the clause grammar of

Table 2 Relative selections of PROCESS TYPES of the six readings of annual and monthly cycles

\begin{tabular}{llll}
\hline Process & & Instances & Percentage \\
\hline Material & Happening & 781 & 63.08 \\
$(82.55 \%)$ & Doing & 241 & 19.47 \\
Relational & Attribution & 94 & 7.59 \\
$(9.61 \%)$ & Identifying & 25 & 2.02 \\
Mental & Emotive & 34 & 2.75 \\
$(5.74 \%)$ & Perceptive & 25 & 2.02 \\
& Cognitive & 11 & 0.89 \\
& Desiderative & 1 & 0.08 \\
Behavioural & & 15 & 1.21 \\
Verbal & & 11 & 0.89 \\
& & 1,238 & 100 \\
\hline
\end{tabular}


behaving). Verbal process is the least frequent process type at around $0.89 \%$ (the clause grammar of saying). It is interesting to note that among the selected readings of annual and monthly cycles, there is no instance of existential processes. This suggests that these readings are not concerned with an existence of an entity and/ or event.

Based on the process type distribution, two major motifs of readings of annual and monthly cycles can be detected: (1) processes of expansion unfolding as happeningand-doing, as being and as behaving, which accounts for $93 \%$ and (2) processes of projection unfolding as sensing and as saying, which accounts for $7 \%$ of process types found.

When exploring each process type selection in detail, we find that material process is selected considerably more frequently than any other process types (i.e., over three quarters of clauses instantiated in the six readings). The frequent selection of material process is highly motivated as the readings of annual and monthly cycles are concerned with what happens during the whole year and what activities are activated month by month constituting the Tai Dam whole year activities.

Based on the relative profile of selection presented in Table 2, material clauses are central to readings of annual and monthly cycles, because they construe "events" known as 'happening' material clauses (63.08 \%) and "activities" known as 'doing' material clauses (19.47\%). Over three times as many clauses are happening clauses. 'Happening material' clauses construe some natural 'things' as Actor participants. Those Actor participants are domesticated and non-domesticated plants and animals. They construe a happening act of different participants. Examples of happening material clauses are given below.

Example (9): Text 4: animal participant: emerald dove

$$
\begin{array}{ll}
6.1 \text { no:k4 paw5co:m1 pua1 ma?1 } \\
\text { bird emerald dove enjoy fruit }
\end{array}
$$

A common emerald dove enjoys fruits.

$$
\begin{array}{llll}
6.2 & (\varnothing=\text { man2 }) \text { taj3 ya:4 wa:5 } \quad \text { ma:2 ni:1na:j1 } \\
(\varnothing=\text { it }) \quad \text { climb branch java plum } & \text { come many } \\
\text { (it) climbs a java plum branch. } &
\end{array}
$$

$$
\begin{aligned}
& \text { 6.3 }(\varnothing=\text { man2) taj3 ya:4 wa:j1 ma:2 ni:1nuan5 } \\
& (\varnothing=\text { it }) \quad \text { climb branch rattan come many } \\
& \text { (it) climbs a rattan branch. }
\end{aligned}
$$

From the example illustrated above, clause 6.1 is a mental clause which is expressed by the emotional verb pual 'enjoy'. Clauses 6.2 and 6.3 are material clauses. They are expressed by the same lexical verbs taj3 'to climb'. The inherent participant of clause 6.1 is Senser (i.e., emerald dove), whereas the emerald and its ellipsed form function as Actors, as inherent participants of the material clauses. 
Example (10): Text 1: animal participant: toad

$\begin{array}{llll}49.1 & \text { buan1 cet3 kaP1tu:3 } & \text { to:k3 na:m6 } \\ \text { month seven toad } & \text { fall } & \text { water }\end{array}$

In the seven month, toads fall into the water,

$\begin{array}{ll}49.2 & \begin{array}{ll}\text { lay1 (kai1tu:3) } & \text { ja:1 } \\ \text { backs (toads) } & \text { be rough }\end{array} \\ \text { the backs (of toads) are rough, }\end{array}$

\begin{tabular}{|c|c|c|c|c|}
\hline 49.3 & $\begin{array}{l}(\varnothing=\text { salma:j1) } \\
(\varnothing=\text { they })\end{array}$ & $\begin{array}{l}\text { taj3 } \\
\text { climb }\end{array}$ & $\begin{array}{l}\text { lat4la:2 } \\
\text { crawl }\end{array}$ & $\begin{array}{l}\text { tem1 } \\
\text { be full }\end{array}$ \\
\hline
\end{tabular}

(they) climb and crawl through the brooks.

In the seventh month, toads fall into the water. Their backs are rough. (They) climb and crawl through the brooks.

Toads fall into the water and crawl through the brooks. The appearance of the toads implies that it is the beginning of the rainy season. Clauses 49.1 and 49.3 are material clauses. Clause 49.1 is realized by the lexical verb to: $k 3$ 'fall'. The Process of Clause 49.3 is realized by a serial verb construction ${ }^{6}$ taj 3 + lat4la: 2 'climb and crawl'. The inherent participants of clauses 49.1 and 49.3 are Actors. Clause 49.2 is a relational clause, which is expressed by the lexical verb ja: 1 'be rough'. There are two inherent participants in the relational clauses, Carrier (i.e., toad's back) and Attribute (i.e., be rough).

Example (11): Text 4: 'Plant' participant: onion and Kae Lae

48.1 buan1 cet3 ni:5 ho:m1 Po?1 bo?1 ?æ:1sæ:2 month seven this onion bloom flower a lot

In the seventh month, onion flowers are in full bloom.

$\begin{array}{lll}48.2 & \text { kæ:1læ:2 } & \text { Po?1 bo?1 la:j2 lian4 } \\ \text { Kae Lae } & \text { bloom flower a lot }\end{array}$

Kae Lae flowers are in full bloom.

'Onion flowers' and 'Kae Lae flowers' (a plant found in Vietnam) are in full bloom. Both clauses 48.1 and 48.2 are material clauses which are expressed by the same lexical verb Pว?1 'to bloom'. The 'onion' and 'Kae Lae' function as Actors in the material clauses.

In addition, the 'happening material type' also deals with social activities. For example, in the fifth month, Tai Dam people are free from farming activities and so take the opportunity to visit their family and friends as illustrated in example 12 .

Example (12): Text 1

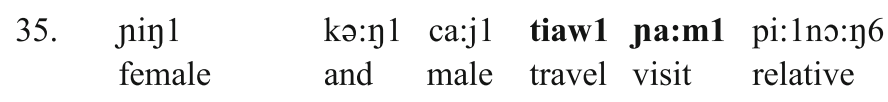

Male and female Tai Dam travel and visit their relatives. 
Clause 35 is constructed by a serial verb construction: lexical verb tiaw1 'travel', which is a happening material clause and na:m2 'visit', which is a doing material clause. In this example, 'human beings' (i.e., female and male Tai Dam) function as Actors.

The doing material processes are construed in terms of actions and activities. Based on transitivity analysis, Tai Dam activities are divided into three categories: social activities, agricultural activities, and ritual activities.

The social activities include collective work done by the Tai Dam people. For example, the third month is believed as a good months, so the Tai Dam make mattresses to be given to relatives, as shown in example 13.

Example (13): Text 4

$\begin{array}{llllll}21.1 & \text { buan1 sa:m1 buan1 } & \text { taj1 } & \text { Pet3 } & \text { sut3 } & \text { waj6 kha:3 } \text { Pa:1 } \\ \text { month three } & \text { month } & \text { the Tai Dam } & \text { make } & \text { mattress, } & \text { keep give uncle }\end{array}$

In the third month, the Tai Dam people make mattresses to be given to uncles.

Clause 21.1 is a material clause with lexical verbs ?et3 'make' and waj6 'keep' as Process. It forms a serial verb construction. The 'Tai Dam' functions as the Actor-the one doing the material deed, whereas sut 3 'mattresses' functions as the Goal-a participant impacted by a doing.

As for the agricultural activities (both main and supportive agricultural activities), doing material clauses are manifested in the ninth and eleventh months. As it rains around the ninth month, the Tai Dam start their agricultural activities by preparing rice fields, ploughing, and harrowing. This is followed by transplanting rice seedlings in the eleventh month as illustrated in example 14.

Example (14): Text 1

$\begin{array}{lllllll}79.1 & \text { buran1 sip32et3 } & \text { ta:n1 } & \text { lo:k3 } & \text { ka:5 } & \text { ko:1 } & \text { kam3 } \\ \text { month eleven } & \text { you } & \text { pull out } & \text { seedling } & \text { tree } & \text { be beautiful }\end{array}$

In the eleventh month, you pull out beautiful seedlings,

$79.2(\varnothing=$ ta:n1 $)$ pa:1 phuan1ba:n1 ma:2 ba:n5

(you) bring harrow come home

(you) bring a harrow home,

\begin{tabular}{|c|c|c|}
\hline $\begin{array}{l}(\varnothing=\operatorname{ta}: n 1) \\
(\text { you })\end{array}$ & $\begin{array}{l}\text { wa:n5 mæ:4 kwa:j1 } \\
\text { herd mother buffalo }\end{array}$ & $\begin{array}{ll}\text { puun1 kwa:j1 } \\
\text { drove } & \text { buffalo }\end{array}$ \\
\hline
\end{tabular}

(and you) drive a herd of buffalo to be tied in the cattle pen.

In the eleventh month, you pull out beautiful seedlings, and (you) bring a harrow home, (and you)

drive a herd of buffalo to be tied in the cattle pen.

Clauses 79.1-79.3 are doing material clauses with Processes realized by the lexical verbs lo:k3 'pull out' (in clause 79.1), pa: 1 'bring' (in clause 79.2) and wa:n5 'herd' (in clause 79.3). ta:n1 'you' and its ellipsed form function as the Actors. Each 'doing' 
material clause takes different participants as the Goals (e.g., seedlings, a harrow, a drove of buffalo).

As for the ritual activities, materials used in ritual offerings are gathered and prepared. In the seventh month, different groups of people, including 'grandmother' as found in Texts 1, 2, 3 and 6, 'aunt-in-law, 'old lady and unmarried lady' as found in Text 4, and 'jungle man' as found in all six texts, go out to gather bamboo shoots. For example:

\section{Example (15): Text 3}

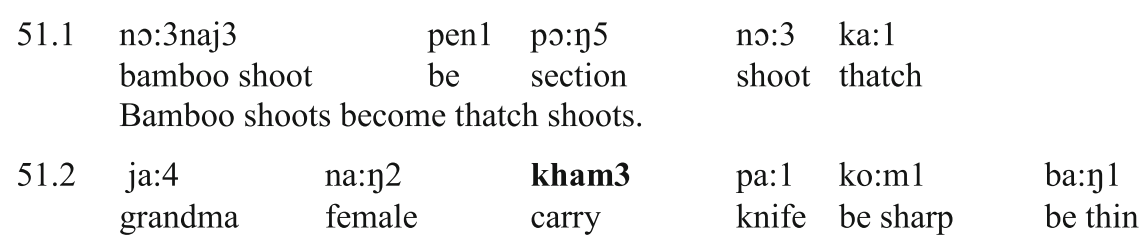

A grandma carries a sharp and thin knife,
$51.3(\varnothing=$ saw2) ma:2 khut3 (nэ:3naj3)
(she) come dig (bamboo shoot)

(she) harvests (the bamboo shoots).

$\begin{array}{llllll}51.4 & \text { sa:5 } & \text { kham3 } & \text { dua5 } & \text { khut3 } & \text { (no:3naj3) } \\ & \text { jungle man } & \text { carry } & \text { spade } & \text { dig } & \text { (bamboo shoot) }\end{array}$

A jungle man carries a spade and harvests (the bamboo shoot),
$51.5(\varnothing=$ saw2) ma:2 pua1 (no:3naj3)
(he) come take (bamboo shoot)

(he) takes (the bamboo shoot).

Bamboo shoots become thatch shoots, (and) a grandma carries a sharp and thin knife, (and she) harvests (the bamboo shoots). A jungle man carries a spade and harvests (the bamboo shoot), (and he) takes (the bamboo shoot).

Clauses 51.2-51.5 are doing material clauses, with Processes realized by three lexical verbs: kham 3 'carry' in 51.2 and 51.4, khut3 'dig' in 51.3, pual 'take' in 51.5. In terms of participant roles, various participants function as Actors (i.e., 'grandma' as in 51.2; the ellipsed third personal pronoun as in 51.3; jungle man as in 51.4; and the ellipsed third personal pronoun as in 51.5). Instruments (i.e., a knife and a spade) are Goals; bamboo shoots (in clauses 51.3 and 51.5) are omitted Goals.

In relation to actual practices in the Tai Dam community, the bamboo shoots are crushed and fermented in earthenware jars to make "sour bamboo shoots". They are used as an ingredient in a key dish in all Sen rituals (i.e. ka: :1n 1 :3som5).

The second month is a month of restraint. Tai Dam people are prohibited from doing many activities, such as building a house, making baskets to be used in various Sen rituals called pa:nlphuanl, making mattresses or furniture as illustrated in example 16. 
Example (16): Text 4

$\begin{array}{llllll}\text { 11.2 } & \text { buan1 ni:3 } & \text { ni:5 } & \text { buan1 } & \text { taj1 } & \text { pam5 maj6 } \\ \text { month two } & \text { this } & \text { month } & \text { the Tai Dam } & \text { cut tree }\end{array}$

In the second month, the Tai Dam people cut down trees,

$11.3(\varnothing=$ salma:j1) bo:3 $\quad$ et3 huan2

(they) NEG. build house

(they) do not build houses.

11.4 taj1 bo:3 sa:n1 phuan1

the Tai Dam NEG. weave Sen Huen basket

The Tai Dam people do not weave baskets.

14.4 la:n2 sa:w1 thaw5 sa:y5 huan2

if lady be old build house

If an old lady builds a house,

$14.5(\varnothing=$ saw2) la:n2mo:n1

(she) be sad

(she) will be sad.

15.1 buan1 ni:3 buan1 taj1 $\quad$ Pet3 sut3 waj6

month two month the Tai Dam make mattress, keep

In the second month, (if) the Tai Dam people make mattresses,

$15.2(\varnothing=$ salma:j1 $) \quad$ mo:y1

(they) be sad

(they will be) sad.

15.3 buan1 taj1 Pet3 co:n1 waj6

month the Tai Dam make bed keep

It is the month in which the Tai Dam people make beds,

$15.4 \quad(\varnothing=$ sa1ma:j1 $) \quad$ pa:w3

(they) empty

(but they) remain empty.

In the second month, the Tai Dam people cut down trees, (but they) do not build houses. The Tai Dam people do not weave baskets. If an old lady builds a house, (she) will be sad. In the second month, the Tai Dam people make mattresses, (but they) are sad. It is the month in which the Tai Dam people make beds, (but they) remain empty.

Clauses 11.2-11.4 express material processes, with Processes realized by the lexical verbs pam5 'cut', ?et3 'build' and sa:nl 'weave'. Nominal groups denoting the Tai Dam people and third personal pronouns referring to them function as Actors, and various other participants (i.e., tree, house, and bamboo basket) function as Goals. Clauses 14.4, 15.1 and 15.3 are doing material clauses. Two lexical verbs are used to 
express material clauses: $s a: \eta 5$ 'build', Pet3 'make'. The inherent participants are nominal groups denoting Tai Dam females and Tai Dam people functioning as Actors. The inherent Goals are nominal groups denoting houses, mattresses and beds.

In contrast, the third month is considered a good month. Tai Dam people often make household items to be given to relatives and females, such as mattresses, blankets, and beautiful items as shown in example 17.

Example (17): Text 4

\begin{tabular}{|c|c|c|c|}
\hline uran1 & $\begin{array}{l}\text { taj1 } \\
\text { the Tai Dam }\end{array}$ & $\begin{array}{l}\text { Pet3 } \\
\text { make }\end{array}$ & $\begin{array}{l}\text { sut3 } \\
\text { mattresses }\end{array}$ \\
\hline
\end{tabular}

It is the month in which the Tai Dam people make mattresses to be given to uncles.

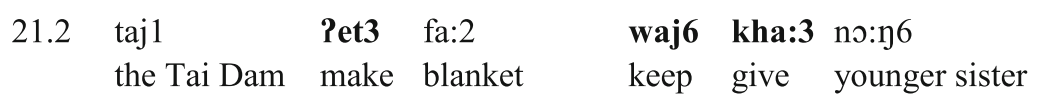

The Tai Dam people make blankets to be given to younger sisters.

$\begin{array}{lllll}21.3 & \text { taj1 } & \text { Pet3 } & \text { cuan1no:y5 } & \text { waj6 kha:3 ni:n1sa:w1 } \\ \text { the Tai Dam } & \text { make } & \text { beautiful item } & \text { keep give lady }\end{array}$

The Tai Dam people make beautiful items to be given to ladies.

It is the month in which Tai Dam people make mattresses to be given to uncles. Tai Dam people make blankets to be given to younger sisters. Tai Dam people make beautiful items to be given to ladies.

Clauses 21.1-21.3 are doing material clauses, with Processes realized by only one lexical verb ?et3 'make'. In the doing material clauses, the Actors are Tai Dam people, whereas the Goals are mattresses, blankets, and beautiful items.

Relational processes are the second most frequent process type. The main characteristic of a relational process is that it relates a participant role to its description or identity. Relational processes can be subdivided into two subtypes: attributive subtype (7.59 \%), and identifying subtype $(2.02 \%)$. The attributive subtype was selected three times more frequently than the identifying one.

Attributive relational clauses are used to relate, describe, and convey general characteristers. They are used to describe (1) participants, which can be animals, plants, and entities, as shown in examples 18-20 and (2) circumstances of place and time: court yard (as in example 21) and the third month (as in example 22).

Example (18): Text 1: plant: rice

27. buan1 si:3 khaw5na:2 ta:w5 na:2
month four

In the fourth month, your rice fields turn ripe and yellow. 
Example (19): Text 3: animal: toad

$\begin{array}{lll}44.1 & \text { ka21tu3 } & \text { to:k3 na:m6 } \\ \text { toad } & \text { fall } & \text { water }\end{array}$

Toads fall into the water.

44.2 lay1 (ka91tu:3) ja:1

back (of toads) rough

...the backs (of toads) are rough.

Toads fall into the water. Their backs are rough.

Example (20): Text 6: entity: sky

\section{5 fa:6 Pum1tum1 \\ sky be cloudy \\ The sky is cloudy.}

Examples $18-20$ are attributive relational clauses. They describe the characteristics of Carrier roles: rice is ripe and yellow (in example 18), the backs (of toads) are rough (in example 19), and the sky is cloudy (in example 20). In Tai Dam, the 'quality' of entities (i.e., rice, the backs (of toads) and the sky) is construed in an 'attributive' clause as "Process/Attribute": su:k3lmayl 'ripe \& yellow', ja:1 'be rough' and ?umltuml 'be cloudy

Example (21): Text 2: circumstance: place

\section{1 khuan3 ju:3 læ:引6 \\ court yard be is parched}

The court yard is parched,

$$
\begin{aligned}
& 64.2(\varnothing=\operatorname{man} 2) \quad \text { pen1 tom } 1 \\
& (\varnothing=\text { it }) \text { be be muddy }
\end{aligned}
$$

(it) is muddy.

The court yard is parched, (it) is muddy.

Example (22): Text 4: circumstance: time
20.2 buan1 sa:m1 buan1
di:1
lam3taw5 di:1 la:j1
month three month
be good
a lot
In the third month, it is a very good month.

In examples 21 and 22, the court yard with its ellipsed pronoun (in example 21) and the third month (in example 22) function in the role of Carrier. They are described as being in drought and muddy (in example 21) and as being good (in example 22), which function in the Attribute roles. 
In addition, in example 21, clause 64.2, the 'quality' is construed as Process: pen1 'be' + Attribute: toml 'to be muddy'.

Significally, attributive relational clauses are also deployed to construe ritual practices. For example, a pig is raised and it becomes old and ready for use as the key offering in the Sen Ruan. Homemade liqour is brewed and prepared as an offering to ancestral spirits and served during feasts and banquets as shown in example 23 .

Example (23): Text 2: ritual practice

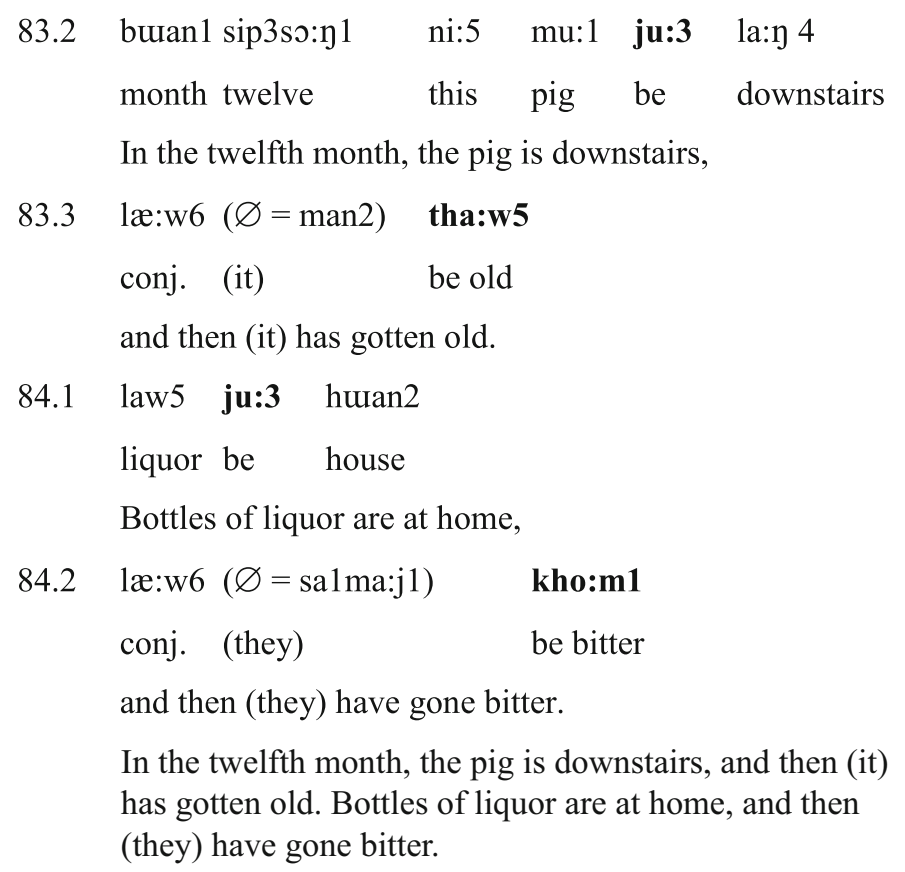

Clauses 83.2-84.2 are attributive relational clauses. Clauses 83.2 and 84.1 are circumstantial attributive relational clauses, with places such as huan2 as Attribute, whereas clauses 83.3 and 84.2 are intensive attributive relational clauses, with qualities such as kho:ml as Attribute. These are attributed to the pig or the bottles of liquor as Carrier, but the references are implicit since they are recoverable. The pig is downstairs and it has gotten old. The bottles of liquor are at home and they have gone bitter. The locations (downstairs and home) feature in circumstantial Attribute roles, whereas the described features of the pig and the bottles of liquor function in intensive Attribute roles.

As for the identifying relational clauses, they are used to relate participants to their identities and roles. There were only 25 instances found. For example:

Example (24): Text 5

$\begin{array}{lllll}\text { 20. buan1 sa:m1 pen1 buan1 } & \text { di:1 } & \text { lam3taw5di:1la:j1 } \\ \text { month three be } & \text { month } & \text { be good } & \text { a lot }\end{array}$

The third month is a very good month. 
Example 24 explains that the third month is a good month. It is an identifying clause which is realized by the lexical verb pen1 'be'. It manifests two participants: Token + Value. In the above example, 'the third month' is Token, whereas 'good month' is Value.

Toward the end of the readings of annual and monthly cycles, the word 'guardian angel' (mo:n2) is mentioned several times. The guardian angel shines onto the water and it becomes a fish; it shines onto rice fields and they become rice grains; it shines onto cities and they become noble people. Metaphorically, this suggests fertility of the land and prosperity in life as shown in example 25.

Example (25): Text 6

$\begin{array}{lllll}95.1 & \text { mo:n2 } & \text { te: } 11 \text { hua1 pi:1 wa:y3 } \\ & \text { guardian angel } & \text { above head } & \text { wing spread }\end{array}$

The guardian angel above the head spreads its wings,

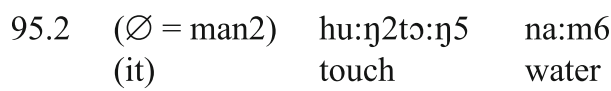

(it) touches water,
$95.3(\varnothing=\operatorname{man} 2) \quad \mathrm{k}$ :3 3 pen1 pa:1
(it) conj. be fish

then (it) becomes fish,

$95.4(\varnothing=\operatorname{man} 2) \quad$ hu:p2to:y5 na:2

(it) touch rice field

(it) touches rice fields,

$\begin{array}{llll}95.5 & (\varnothing=\text { sa1ma:j1) } & \text { ko:3 } & \text { pen1 khaw5 } \\ \text { (they) } & \text { conj. } & \text { be rice }\end{array}$

then (they) become rice grains,

$\begin{array}{lll}95.12(\varnothing=\operatorname{man} 2) & \text { hu:n2to:n5 } & \text { muan2 } \\ \text { (it) } & \text { touch } & \text { city }\end{array}$

(it) touches the cities,
$95.13(\varnothing=$ sa1ma:j1) ko:3 pen1 ta:w5
(they) conj. be noble person

then (they) become noble persons.

The guardian angel above the head spreads its wings, (it) touches the water, then (it) becomes fish, (it) touches rice fields, then (they) become rice grains... (it) touches the cities, then (they) becomes noble persons.

In example 25, clauses 95.3, 95.5, 95.13 are identifying relational clauses. They are expressed by the lexical verb pen1 'be'. The ellipsed third personal pronouns, which refer to mo:n2 or guardian angel, function as Token and the identified participants (i.e., fish, a grain of rice, noble person) are Value roles. 
Mental processes are profiled as the third most common process type. Mental clauses construe processes of sensing; they are distinguished grammatically into four subtypes: emotion subtype (2.75\%); perception subtype $(2.02 \%)$; cognition subtype $(0.89 \%)$; desideration subtype $(0.08 \%)$.

The inherent participant of the mental clause is the Senser-the participant sensing. Both animate (e.g., plants and animals) and inanimate (e.g., house, window, mattress) participants can sense. In this particular readings, when non-conscious entities are construed as Senser, they are "personified". In addition, the mental clauses may involve one further type of participant, namely the Phenomenon being sensed. Examples 2628 illustrate animates as Sensers and examples 29-30 are examples of inanimate participants as Sensers.

Example (26): Text 2: animate: seedling

$$
\begin{array}{lll}
78.4 & \text { ka:5 } & \text { muan4 } \\
& \text { seedling } & \text { be happy }
\end{array}
$$

The seedling is happy.

Example (27): Text 4: animate: frog and small green frog

$$
\begin{array}{lll}
\text { 77. } & \text { ko:p3 khiat1 } & \text { co:m1 na:m6 na:2 } \\
\text { frog } & \text { small green frog } & \text { enjoy water rice field }
\end{array}
$$

Frogs and small green frogs enjoy water from the rice field.

Example (28): Text 5: animate: ants

$$
\begin{array}{ccccc}
56.1 & \text { cu:1 mo:t4 } & \text { hu:6 } & \text { sæ:y1 } \\
& \text { all ant } & \text { know } & \text { light }
\end{array}
$$

All ants know light.

In examples 26-28, animate participants, as Sensers (i.e., seedlings, frogs, all ants), sense emotive feelings (i.e., happiness in example 26, enjoyment in example 27) and cognitive senses (i.e., knowing in example 28). Example 18 does not involve other participants, whereas examples 27 and 28 involve Phenomena which are being sensed. Here, two participants (i.e., water from the rice field in example 27 and light in example 28) are Phenomena which are sensed by the frogs and all ants.

Example (29): Text 6: inanimate: sky

$$
\begin{aligned}
& \text { 48.1 buan1 ho:k3 ni:5 fa:6 yin2 to:k3 } \\
& \text { month six this sky hear sadness } \\
& \text { In the sixth month, the sky hears sadness. }
\end{aligned}
$$

Example (30): Text 5: inanimate: guardian angel
81.3 mo:n2
to:y5 pa:1
guardian angel
see fish
The guardian angel sees a fish. 
In examples 29-30, inanimate sky and guardian angel are Sensers which sense the perceptive senses of hearing, in example 29, and seeing, in example 30. Sadness and fish are Phenomena being sensed by the sky and the guardian angel respectively. Here, the inanimate participants who sense are characterized through personification.

While non-human participants are restricted to certain subtypes of mental processes (i.e., emotion, perception and cognition), human participants, as Sensers, possess a wide range of senses: emotions, perceptions, cognition, and desires as shown in examples $31-34$.

Example (31): Text 3: old man: emotive mental clause

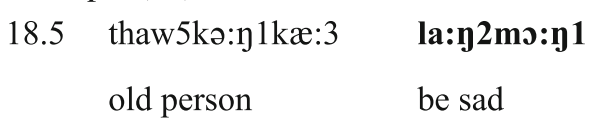

An old person is sad.

Example (32): Text 5: Tai Dam: perceptive mental clause

$\begin{array}{llll}5.5 & \text { taj1 } & \text { du:1 } & \text { do:j1 } \\ & \text { Tai Dam } & \text { see } & \text { hill }\end{array}$

A Tai Dam person sees a hill.

Example (33): Text 6: guest: cognitive mental clause

\section{1 khæ21 hu:6 \\ guest know \\ Guests know.}

Example (34): Text 1: young lady: desiderative mental clause

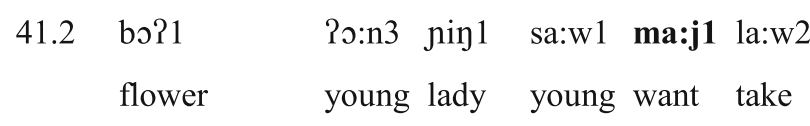

A young lady wants a young flower.

Examples 31-34 are mental clauses. Different participants function as Sensers (i.e., an old person, a Tai Dam person, guests and a young lady). Those participants sense emotions (being sad), perceptions (seeing), cognition (knowing), and desires (wanting). Examples 31 and 33 do not take Phenomena roles, while examples 32 and 34 take Phenomena roles (i.e., hill and young flower). In Systemic Functional Linguistics, Phenomena are optional participants. They refer to things which are perceived, thought about, felt (emotionally), and desired. 
From some of the examples presented above, the mental clauses are construed through time (month by month) and organised in terms of seasons which are closely related to agricultural activities. Different kinds of animals enjoy nature, that changes according to the seasons. The tenth month is the rainy season in Vietnam. Fish, frogs, small green frogs come out to enjoy the fresh water (as in example 27 above). After that happens, the Tai Dam will start transplanting rice seedlings.

Behavioural processes are processes of behaving. They ranked fourth in terms of frequency. They construe human behaviour including mental and verbal behaviour: as an active version of mental and verbal processes (Martin et al. 2010: 107). There are 15 instances of behavioural processes. The only inherent participant of the behavioural clauses is the Behaver-the one who behaves. The Behaver participants can be either human or non-human (e.g., buffalos and insects). Human, animals and plants can be construed grammatically as participants in behavioural processes: laugh, cry, and look at. Some examples are given below.

Example (35): Text 1: human: lady

$\begin{array}{lll}50.4 & \text { sa:w1 da:j1 } & \text { hua1 } \\ & \text { lady beautiful laugh }\end{array}$

A beautiful lady laughs.

Example (36): Text 6: non-human: cicada

68. buan1 kaw5 ni:5 cak3can3 kaw1 do:n1 sa:j2
month nine this cicada $\quad$ cry hill
In the ninth month, cicadas sing on a sand hill.

Example (37): Text 1: non-human: buffalo

$\begin{array}{rlllll}75.2 & \text { ta:1 } & \text { kwa:j1 } & \text { can3 læ:2du:1 nan3 ho:n4 } \\ & \text { eye } & \text { buffalo } & \text { conj. look at } & \text { at } & \text { ditch }\end{array}$

The buffalo's eyes look at a ditch.

Examples 35-37 are behavioural clauses. The inherent participants are a beautiful lady, cicadas and buffalo's eyes which function as Behavers. They perform active versions of the verbal clause (i.e., laugh and cry as in examples 35 and 36) and of the perceptive mental clause (i.e., look at as in example 37).

Verbal processes are minor processes in terms of frequency (11 instances). They represent processes of saying in speech events. The saying processes are construed by the verbal processes of calling and talking. There are 11 instances of verbal processes. Five instances have the shaman serving as a Sayer (e.g., khap3 'chant', 
$k a: w 3$ 'say') and the other 6 instances have different participants serving as a Sayer (e.g., guest-wa:4 'score', person-phu:t2 'speak', young lady-ku:3wa:y2 'call', Tai Dam-khuj2 'talk', bird and insect-Pa:n3 'count').

In the readings, the speaker is construed as the Sayer of a verbal clause. The Sayer can be either non-human (e.g., birds and insects) or human. The non-human Sayers are expressed in metaphoric realization as shown in example 38.

Example (38): Text 1: verbal \& temporal and spatial location

$\begin{array}{lllll}\text { 83. } & \text { buan1 sip3so:n1 } & \text { nok4 } & \text { cæ:n1wæ:n2 } & \text { Pa:n3 pa:j1 ta:y5 } \\ \text { month twelfth } & \text { bird Caeng Waen count top } & \text { Sesbania trees }\end{array}$

(Literal meaning) In the twelfth month, Caeng Waen birds count the tops of Sesbania trees.

(Metaphorical meaning) In the twelfth month, there are many CaengWaen birds in the tops of Sesbania trees.

84. sæ:n1 mæ:y2 ywa:y6 Pa:n3 ko:n1ha:w2

a lot insect $\quad \mathrm{Nga} \quad$ count door lock

(Literal meaning) Many insects count door locks.

(Metaphorical meaning) There are many Nga insects flying around door locks.

Lexicogrammatically, clauses 83 and 84 are verbal clauses which are realized by the lexical verb Pa:n3 'count (out loud)'. Here, the Caeng Waen birds and insects are Sayers, which are personified. As the readings were written in a poetic style, nonhumans functioning as Sayers (i.e., the Caeng Waen birds and insects) are given human characteristics (i.e., personification) as depicted through the verbal processes described (i.e., count). Metaphorically, clauses 83 and 84 are translated into existential clauses.

Focusing on an ecological interpretation, in the twelfth month there are many birds and insects. Many birds are in the tops of Sesbania trees and numerous insects fly around door locks (Literally, birds and insects count the tops of Sesbania trees and door locks). It shows a period of animal productivity.

When human beings are Sayers, verbal clauses are particularly related to social activities. The third month is an auspicious month and family matters are one of the main concerns. Wives call their husbands to return home as shown in example 39. The Tai Dam visit family and friends in the fifth month. They are encouraged to do social activities, e.g. discussing marriage as shown in example 40.

Example (39): Text 6

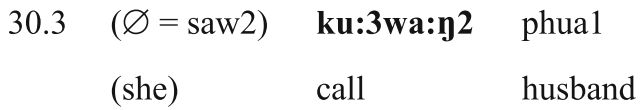

(She) calls her husband. 
Example (40): Text 4

29.

$\begin{array}{lllll}\text { taj1 } & \text { waw6 } & \text { to:1 } & \text { kuaj3 } & \text { kə:n1d } 1: \text { 1 } \\ \text { Tai Dam } & \text { discuss } & \text { continue } & \text { about } & \text { marriage }\end{array}$

A Tai Dam discusses about marriage.

In examples 39 and 40, the verbal clauses have Processes realized by the lexical verbs ku:3wa:y2 'call' and waw6 'discuss' + to:1 'continue'. The Sayers are the third personal pronoun (she) in example 39 and Tai Dam in example 40 .

\section{Circumstantial transitivity profile of readings of annual and monthly cycles: process type and circumstantiation}

Circumstantial transitivity is concerned with the resource for expanding the process along various circumstance types. Process type and circumstantiation are the two major aspects of the system of TRANSITIVITY. It is a significant step to investigate the intersection of these two simultaneous systems. Table 3 below shows the intersection of process types with circumstantiation in the texts analyzed (i.e., circumstantial types) to illustrate possible favored and nonfavored combinations of the two systems.

Table 3 shows that the circumstances of the temporal location subtype are the most frequently selected (43.23\%). Throughout the development of the readings, the ancestral spirits as listeners are oriented through time month by month. In addition, the spatial location subtype is ranked second in terms of frequency $(33 \%)$. It is used in the readings where various activities take place. It is also deployed when the shamans inform the ancestral spirits about spatial location of season, agriculture, social, and ritual activities.

This table also illustrates that there are clearly favored and non-favored combinations of process types and circumstantial types.

A combination of material and temporal location (320 instances) and spatial location (220 instances) was highly favored. The material clauses accounted for 68.26 \% of locative circumstances. Tai Dam material clauses preferred temporal location over spatial location. This selection differs from the result of an analysis of the English transitivity system reported by Matthiessen (1999: 20). Based on his analysis of a range of various registerial domains (e.g., narratives and news reports), material clauses accounted for $58.9 \%$ of circumstances of location (388 instances out of 658 circumstantial instances) and favoured the spatial location over the temporal location.

Spatial location (287 instances) was chosen nearly three times more than temporal location (101 instances). However, when working at a lower degree of delicacy, these two researches revealed similar findings; material clauses were highly favoured as the environment of circumstances of location. 
Table 3 Distribution of circumstances across process types

\begin{tabular}{|c|c|c|c|c|c|c|c|c|c|c|c|c|}
\hline \multirow[t]{2}{*}{ Circ. } & \multirow[t]{2}{*}{ Subtype } & \multicolumn{2}{|l|}{ Material } & \multicolumn{2}{|l|}{ Relational } & \multicolumn{3}{|l|}{ Mental } & \multirow[t]{2}{*}{ Behav } & \multirow[t]{2}{*}{ Verbal } & \multirow[t]{2}{*}{$\#$} & \multirow[t]{2}{*}{$\%$} \\
\hline & & Happening & Doing & Attributive & Identifying & Emotion & Perception & Cognition & & & & \\
\hline \multirow[t]{2}{*}{ Locative } & Time & 285 & 35 & 13 & 1 & 2 & 4 & 1 & - & 1 & 342 & 43.23 \\
\hline & Place & 198 & 22 & 35 & - & 3 & - & - & 1 & 2 & 261 & 33 \\
\hline \multirow[t]{4}{*}{ Manner } & Means & - & 2 & - & - & - & - & - & - & - & 2 & 0.25 \\
\hline & Quality & 35 & 11 & 9 & - & 1 & - & - & 1 & 1 & 58 & 7.33 \\
\hline & Comp & - & 2 & - & - & 1 & - & - & - & - & 3 & 0.38 \\
\hline & Degree & 83 & 1 & 17 & 1 & 3 & - & - & - & 1 & 106 & 13.40 \\
\hline \multirow[t]{3}{*}{ Cause } & Reason & - & - & - & - & - & - & - & - & - & - & - \\
\hline & Purpose & 3 & 12 & - & - & - & - & - & - & - & 15 & 1.90 \\
\hline & Behalf & - & - & - & - & - & - & - & - & - & - & - \\
\hline \multirow[t]{3}{*}{ Extent } & Duration & - & 1 & - & - & - & - & - & - & - & 1 & 0.13 \\
\hline & Distance & - & - & - & - & - & - & - & - & - & - & - \\
\hline & Frequency & - & - & - & - & - & - & - & - & - & - & - \\
\hline \multirow[t]{2}{*}{ Role } & Guise & - & - & - & - & - & - & - & - & - & - & - \\
\hline & Product & - & 1 & 1 & - & - & - & - & - & - & 2 & 0.25 \\
\hline Matter & & - & - & - & - & - & - & - & - & 1 & 1 & 0.13 \\
\hline Total \# & & 604 & 87 & 75 & 2 & 10 & 4 & 1 & 2 & 6 & 791 & $100 \%$ \\
\hline Total \% & & 76.36 & 11.00 & 9.48 & 0.25 & 1.26 & 0.51 & 0.13 & 0.25 & 0.76 & 791 & $100 \%$ \\
\hline
\end{tabular}


Examples of selection of material clauses attached to temporal and spatial location circumstances are given below (Processes are underlined, Circumstances are in bold).

Example (41): Text 3: material \& temporal location

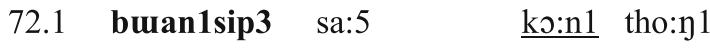 month ten jungle man carry bag}

In the tenth month, jungle men carry bags.

Example (42): Text 6: material \& spatial location

9.1 fo:n1 to: $\mathrm{k} 3 \quad \operatorname{tap} 3$ saj2ka:1
rain fall onto roof
It is raining onto the roof.

Example (43): Text 4: material \& temporal \& spatial locations

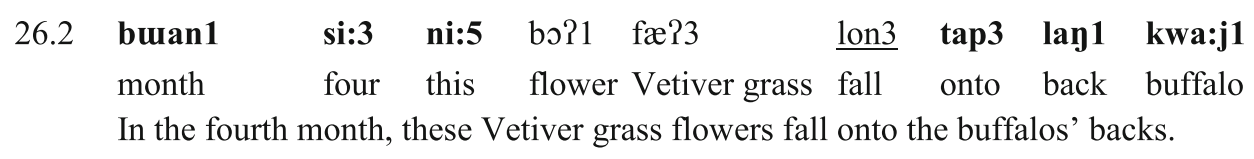

In addition, there are clear selective patterns. For example, there is a prominence of 'manner of degree' and 'manner of quality' circumstances for material clauses (as shown in examples 44-47) and restriction of 'manner of means', 'extent of duration', and 'cause of purpose', for material clauses (as illustrated in examples 48-50). Similarly, circumstance of matter is drawn to a verbal clause (one instance) as shown in example 51. Circumstance of degree manner is more strongly associated with material (84 instances) than relational (18 instances) and mental clauses (3 instances). Examples are given as follows:

Example (44): Text 2: material \& manner: degree

65. na:m6 nэ:n2 dæ:y1 la:j1ha:3

water flood red a lot

The water floods a lot.

Example (45): Text 1: relational \& manner: degree

$\begin{array}{llll}\text { 52. } & \text { kæ:1 } & \text { pen1 bo?1 } & \text { la:j2lian4 } \\ \text { Agasta } & \text { be } & \text { flower } & \text { a lot }\end{array}$

Agasta turns into many flowers.

Example (46): Text 4: emotive mental \& manner: degree

6.1 no:k4 paw5co:m1 pua1 ma?1 la:j1

bird emerald dove enjoy fruit many

A common emerald dove enjoys many fruits. 
Example (47): Text 1: material \& manner: quality

69.2 na:m6 nิ:n2 dæ:n1

water flood red

The water floods and turns red.

Example (48): Text 4: material \& manner: means
68

$\underline{\text { su:m1 }} \quad$ lua1 ko:n1ko:1
The Tai Dam
put on fire big log
The Tai Dam people build fires using big logs.

Example (49): Text 3: material \& extent: duration

37.7 sa:w2 $\underline{\text { ?et3 }}$ tæ: 3 tho: 3 wen2 diaw1
he do only half day one
He does (it) for only half a day.

Example (50): Text 1: material \& cause: purpose
11.1 ta:n1 bo:3 pam5 ma:j6 Pet3 huan2
you NEG. cut tree build house
You do not cut down trees in order to build a house.
11.2 ta:n1 bo:3 sa:n1 phuan1 su:5 kha?1
you NEG. weave container welcome guest

You do not cut down trees in order to build a house. You do not weave a basket in order to welcome guests.

Example (51): Text 4: verbal \& matter

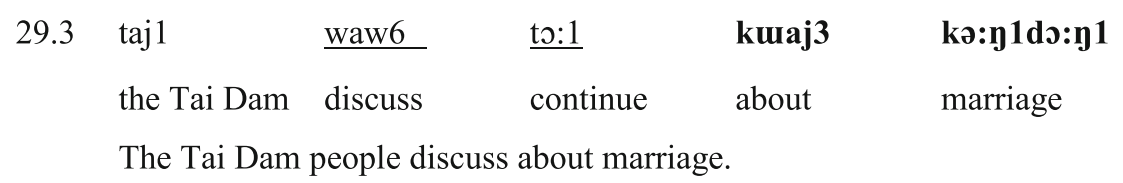

Material and relational clauses tend to combine with a wider range of circumstantial types than the other clause types. Mental, behavioural and verbal clauses tend to have the same selection pattern. They select for circumstance of location and manner. Examples are presented below.

Example (52): Text 6: perceptive mental \& temporal location

$\begin{array}{lllllll}48.1 & \text { buan1 } & \text { ho:k3 } & \text { ni:5 } & \text { fa:6 } & \text { nin2 } & \text { to:k3 } \\ \text { month } & \text { six } & \text { this } & \text { sky } & \text { hear } & \text { sadness }\end{array}$

In this sixth month, the sky hears sadness. 
Example (53): Text 6: cognitive mental \& temporal location

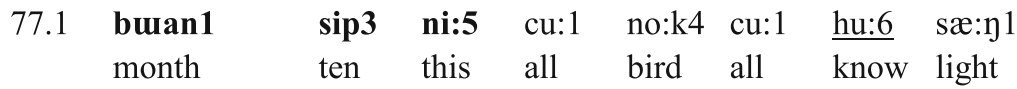

In this sixth month, all birds know light.

Example (54): Text 4: cognitive mental \& spatial location

59. cu:1 po:y5 ma:j5 hu:6 ca:n1 nay5 pa:3

all part tree know cry in forest

All parts of trees know to cry in the forest.

Example (55): Text 6: emotive mental \& spatial location

86.1 cu:1 pa:1 pæ:n5 co:m1 na:m6 mau1

all fish Paen enjoy water new

All Paen fish enjoy the new water,

$86.2(\varnothing=$ salma:j1)

co:m1 kə:y5tæ:3

ta:1 Pu:1 kho:n1

(they)

enjoy under

pier Mae Khong river

(they) enjoy (it) under the pier of the Mae Khong river.

All Paen fish enjoy the new water, (they) enjoy (it)

under the pier of the Mae Khong river.

Example (56): Text 5: emotive mental \& temporal location \& manner: degree

$\begin{array}{lllll}\text { 61. buan1 } & \text { kaw5 ni:5 taj1 } & \text { pual ma?1 ni:1na:j1 } \\ \text { month } & \text { nine this the Tai Dam enjoy fruit a lot }\end{array}$

In this ninth month, the Tai Dam people enjoy fruit a lot.

Example (57): Text 1: behavioural \& spatial location

$\begin{array}{lllllll}75.2 & \text { ta:1 } & \text { kwa:j1 } & \text { can3 } & \underline{1 æ: 2 d u: 1} & \text { nan3 ho:y4 } & \text { haten } \\ & \text { eye } & \text { buffalo } & \text { conj. } & \text { look at } & \text { at } & \text { ditch }\end{array}$

The buffalo's eyes look at a ditch.

Example (58): Text 6: behavioural \& manner: quality
13.1 po:1 sa:5 ha:y5 Paw1 ho:n1
person jungle man capture take Hoon
A jungle man captures a Hoon,
$13.2(\varnothing=\operatorname{man} 2)$ ma:1 thu:k1 mæ:4 man2
(it) come reach mother it
(it) reaches its mother,

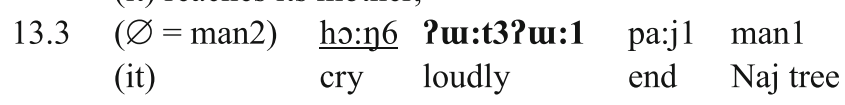
(it) cries loudly at the top of a Naj tree.

A jungle man captures a Hoon, (it) reaches its mother, (it) cries loudly at the top of a Naj tree. 
Example (59): Text 1: verbal \& temporal and spatial location

$\begin{array}{lllll}\text { 83. buan1sip3so:n1 } & \text { nok4 cæ:n1wæ:n2 } & \underline{\text { ?a:n3 }} \text { pa:j1 ta:y5 } \\ \text { month twelfth } & \text { bird CaengWaen count top Sesbania }\end{array}$

(Literal meaning) In the twelfth month, CaengWaen birds count the tops of Sesbania trees.

(Metaphorical meaning) In the twelfth month, there are many CaengWaen birds in the tops of Sesbania trees.

Example (60): Text 1: verbal \& manner: degree

$\begin{array}{lll}\text { 84. sæ:n1 mæ:n2 } & \text { ywa:n6 } & \underline{\text { ?a:n3 ko:n1ha:w2 }} \\ \text { a lot insect } & \text { Nga } & \text { count door lock }\end{array}$

(Literal meaning) Many insects count door locks.

(Metaphorical meaning) There are many Nga insects.

Example (61): Text 5: verbal \& manner: quality

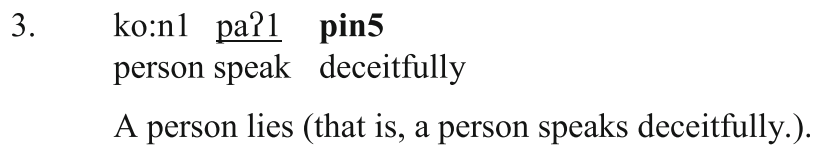

The above findings show that there is a systemic connection between process types and circumstances that can be grammatically explored. This connection is seen in terms of the distribution of circumstances across process types. This distribution reveals the significance of the intersection of the two systems. Matthiessen (1999: 46) explores the significance of the intersection of the two systems noting that "...skewings in the distribution of circumstantial selections across process types indicate that the process types differ from one another in which circumstantial domains of meaning they favoured."

This study was based on one registerial domain (i.e., domestic ritual procedural texts). It reveals certain skewing patterns towards process type selection and favoured and less favoured combinations of process types and circumstances that can be observed. Material and relational processes are the two main process types that were highly selected (see Table 2 above). They favour certain circumstances such as locative circumstances and circumstances of quality and degree manner. The verbal process favours only circumstance of matter (with only instance found). Therefore, it is important to extend the transitivity analysis to other chapters of Sen Huen ritual manuscripts to explore the distribution profile of circumstances across process types.

\section{Conclusion and discussion}

In this paper, the readings of annual and monthly cycles, which are a part of Sen Huen ritual manuscripts, have been analysed showing how the readings are construed grammatically. Experientially, the experiences of ancestral spirits are construed by the system of transitivity. They are modeled by means of configurations of a process, participants directly involved in it and attendant circumstances.

The findings reveal that there is a clear correlation between the semiotic model of time (month by month) and space (geographical space) that is construed by language 
and the material actions that are carried out by different participants (both animate and inanimate). Experience is construed by different process types involving different participant roles in which both human and non-human participants serve according to the process types described above.

Experientially, 'material' clauses were selected more frequently than any other process type $(82.55 \%)$. This suggests that the readings are concerned largely with events (material happenings) through time, space and actions, and actions (material doings) through social, agricultural, ritual practices. The 'relational' clauses construe the nature and identity of various entities (e.g., persons, animals, and plants) (9.61 \%). The 'mental' clauses construe different senses of feeling, hearing, seeing, knowing, thinking, and desiring (5.74 \%). The 'behavioural' clauses construe an active version of verbal and mental processes: laugh, cry, and look at (1.21\%). The 'verbal' clauses construe a sense of verbalization $(0.89 \%)$.

The study also revealed that there is a connection between the process and circumstance configurations expressing the Tai Dam ecological perspective construed by the language. The flow of events was construed and achieved by locative circumstance resources of and circumstances of degree and quality manner. The Tai Dam social, agricultural, and ritual events were ordered in temporal sequences as the monthly cycle unfolds.

Based on the experiential analysis, this study also reveals some aspects of the Tai Dam ecological perspective towards cosmology, beliefs, and way of life. There are interrelationships between the language expressed in the readings and seasons, which in turn relate to social and agricultural activities. For example, the fourth month is a harvesting month (Text 1). Rice fields turn yellow and they are ready to be harvested. After the harvesting period, in the fifth month, the Tai Dam are free, so they travel around and visit family and friends. This reveals social activities (i.e., visiting relatives and friends) of the Tai Dam which relate to the seasonal cycles and agricultural activities. The ninth and the tenth months are in the rainy season in Vietnam so the Tai dam start their agriculture activities: preparing the fields, ploughing, harrowing, and transplanting rice seedlings. The ninth (buan1 kaw5) and tenth months (buan1 sip3) are circumstances of time. They mark the placement of an agriculture cycle. From the examples above, it can be seen that the Tai Dam's way of life is construed in relation to the local seasons, specifically Vietnamese seasons, where the Sen Huen ritual mmanuscripts were initially written. Experience construed monthly is also related to social, agricultural activities of the Tai Dam living in Vietnam.

The readings reflect a relationship of interdependency between seasonal cycles, agricultural cycles and ritual cycles. The seasonal cycles determine the Tai Dam agricultural practices which in turn initiate the agricultural cycles. Agricultural prosperity thereby regulates the ritual cycles. These cycles are realized grammatically by material and relational clauses.

The ritual cycle is an important linkage to establishing and maintaining the socialization cycle of Tai Dam communities within inter and intra families. Tai Dam communities pay a lot of attention to socialization. When they are free from farming activities, they like to visit their family and friends (in the fifth month). The socialization is expressed by material clauses (e.g., tiaw1 na:ml 'travel_visit', na:ml 'visit') and verbal clauses (e.g., phu:t2 'speak', khuj2 'talk', waw6 'discuss'). 
Traditional irrigation (hual fa:jl 'dam') is a key agricultural system in Tai Dam cultivation. In Vietnam, the Tai Dam cultivate upland rice on slopes using the swidden method. Seasonal rainfall and flooding are the major sources of irrigation. This traditional irrigation is interpreted as a circumstance of place.

Based on the Sen Huen ritual manuscript, it reflects that Tai Dam communities living in Vietnam represent a settled and agricultural culture with occasional huntinggathering. They depend heavily on agricultural practices. They are mentioned and realized by material clauses throughout the reading cycles (such as loklka:5 'pull out rice seedlings', dam Ina:2 'transplant rice seedlings'). Tai Dam people rely on natural resources for food and drink used in both daily life and ritual offerings. This connects to other activities such as gathering vegetables and hunting animals in the forest (Trong, 2007: 10). These activities are realized by doing material clauses (e.g., kep3 'harvest', maw5 'collect'). Tai Dam people are keen hunters (e.g., deer and barking deer) and fishermen. Both activities provide necessary supplementary food. Crossbows and traps are common hunting weapons (shown in the third month).

Hunting wild animals and gathering vegetables are common activities in Tai Dam communities. The hunted and gathered are supplementary food sources. Some of the animals hunted and plants harvested are found only in Vietnam. The hunted and gathered items are things which are construed as commodities (no:3 kho:ml 'bitter bamboo shoots', phaklsa:n5 'a kind of vegetable gathered and eaten with chili paste'). These commodities are itemized and valued by means of relational processes (no:3 maj6 p : 75 ba: $\eta 1$ 'bamboo shoots are thin').

From an ecological perspective, the Tai Dam are a good example of an ethnic group who exercises sustainable exploitation of natural resources (Trong, 2007). This is one of the distinctive features of the Tai Dam lifestyle. Such practices are linked to ancient traditions of the Tai Dam community which are concerned with the thoughtful management of land and water.

This study illustrates how the readings of annual and monthly cycles, as one chapter of the Sen Huen ritual manuscripts of the commoner surname group (or phu5 no:j6), are construed grammatically. The grammatical system of TRANSITIVITY was explored. There are other possible research niches available for further work on the Tai Dm ritual discourse. The Sen Huen ritual manuscript, as a domestic procedural text, serves important ritual and social functions which profile various aspects of the Tai Dam including traditional animistic beliefs and way of life. It would be interesting to fully investigate all the Sen Huen ritual manuscripts of both the aristocratic surname group (or phu5 taw5) and the commoner surname group (or phu5 no:j6) in their entirety. Context of situation of these ritual manuscripts and metafunctional analysis of textual and interpersonal meanings should also be explored.

\section{Endnotes}

${ }^{1}$ In the literature, various names are used to refer to Tai Dam such as Black Tai, Lao Song Dam, Song, Lao Song, Thai Song, Tai Song and Thai Song Dam. "Tai" refers to Tai-Kadai speaking people who reside outside Thailand and "Thai" refers to those who live in Thailand. This paper uses "Tai" to address Tai-Kadai speaking people who migrated from other countries (e.g., Laos and Vietnam) to Thailand, i.e., Tai Dam. The name "Tai Dam" or "Black Tai" refers to the black of the women's costume. 
${ }^{2}$ Halliday (2003: 147) explores human history so-called "semohistory" in relation to a change in ways of meaning that is changed in the semiotic construction of reality. The first historical period is settlement: the gradual transition from moving around after food to staying in one place and cultivating it. The second period is the "iron age" of classical Greece, India and China - although these two could be seen as the initiating aspect and the culminating aspect of simple complex transition. The third period is the so-called "renaissance" in Europe, culminating in the industrial revolution. The fourth period is the so-called "information age".

${ }^{3}$ The phonological system of the Tai Dam language is based on Burusphat (2013). Tai Dam has 19 initial consonants and seven final consonants and three cluster consonants (i.e., $k w$-, $k h w$-, and $\eta w$-). There are 21 vowels: 18 are monothongs and four are diphthongs (i.e., $i a, m a, u a$, and $a w$ ). The tones of the Tai Dan language are marked with numbers 1 to 6 . In this paper, tone marks are based on Maneewong (1987). The phonetic features of these tones are as follows: tone $1=$ [23]; tone $2=$ [453]; tone $3=[25]$; tone $4=[342]$; tone $5=[33]$; tone $6=[32]$.

${ }^{4}$ Chavalit Arayayutitham is a retired phu5 no:j6 shaman at Donkhamin village, Dontoom Sub-District, Banglen District, Nakhon Pathom Province, Thailand. He is a local wise man of the Tai Dam community in Thailand. He is one of the teachers teaching reading and writing Tai Dam script to Tai Dam students. In the preface of his Sen Huen ritual manuscript translation (2009), he states that the translated Sen Huen ritual manuscript was checked by Mr. Lo Wan Tan, a local Tai Dam wise man living in Ban Samnue, Muong Lo (or Nghia Lo), Yen Bai, Vietnam. Contents of the other five Sen Huen ritual manuscripts used in this current study are relatively similar to one another. They may vary, but they are not major variants.

${ }^{5}$ In this current study, the readings of annual and monthly cycles are based on the lunar calendar. It approximiates the lunar cycles with "normal-month" pairs that are alternately 29 and 30 days long. 29-day 'hollow months' are odd-numbered; 30-day 'full months' are even-numbered. Month 1 (or buanlciay 1), begins the cycle of counting the months anew, most frequently in December. Successive months (or lunations) are numbered from 1 to 12 within the year.

${ }^{6}$ Tai Dam is like many languages spoken in Southeast Asian region (e.g., Thai, Lao, Burmese, and Vietnamese), in that lexical verbs can be constructed in sequences of two or more verbs, known as a "serial verb construction".

This research was supported by the National Research Council of Thailand (2014-2015) and Mahidol University. I would like to express my thankfulness to Professor Dr. Christian Matthiessen and Assistant Professor Dr. Kazuhiro Teruya for their continued support and encouragement. I am greatly indebted to Mr. Richard Hime for grammatical checking and editing supports.

Received: 5 April 2016 Accepted: 15 June 2016

Published online: 04 October 2016

\section{References}

Anantrawan, Chakrit. 1978. The Phonemic System of Thai Dam Dialect Muban Napanat, Tambon Khao Kaeo, Amphoe Chiang Khan, Loei province. M.A Thesis. Srinakharinwirot University. (in Thai).

Arayayutitham, Chavalit. (Translation). 2009. Tai Dam Poetic Book on Sen Huen Ritual. Tai Dam Association (Thailand). (in Tai Dam).

Aroonkit, Vasana. 1986. Lao Song Ritual and Social Structure. Ph.D dissertation. Chulalongkorn University. (in Thai) 
Aroonkit, Vasana. 1987. Lao Song Ritual and Social Structure. Journal of National Research Council Thailand 19(2): 13-39. (in Thai). Buranasing, Anchulee. 1988. An Analysis of Lexical Change among Three Generations in Thai Song Dialect. M.A. Thesis. Mahidol University. (in Thai)

Burusphat, Somsonge. 2013. Phonological Variation and Change in Thai Song. Songkhla: Phimpakan.

Burusphat, Somsonge, Sujaritlak Deepadung, Sumittra Suraratdecha, Narong Ardsmiti, Pattama Patpong, and Pichet Setapong. 2011. Language Vitality and the Ethnic Tourism Development of the Lao Ethnic Groups in the Western Region of Thailand. Journal of Lao Studies. 2(2): 23-46.

Caffarel, Alice, James R. Martin and Christian M.I.M. Matthiessen 2004. Introduction: systemic functional typology. In Caffarel, Alice, James R. Martin and Christian M.I.M. Matthiessen (eds.), Language Typology: a Functional Perspective. Amsterdam: John Benjamins. 1-76.

Decha, Wilaiwan. 1987. A Comparative Study of Phonological Systems of 6 Tai Languages Spoken in Thatako District, Nakhornsawan Province. MA. Thesis. Chulalongkorn University. (in Thai).

Dechapratumwan, Parada. 2015. A Code-switching in Casual Conversations: a Case Study in Tai Dam Bilinguals at Baan Huathanoon of Nakhon Pathom, PhD. Thesis. Thailand: Mahidol University.

Edwards, Timothy Alan. 2011. Participant Reference in Tai Dam Narrative Discourse. MA. Thesis. Payap University.

Halliday, M.A.K. 1984. Linguistics in the university: the question of social accountability. In New Directions in Linguistics and Semiotics, ed. James E. Copeland, 51-67. Houston: Rice University Studies.

Halliday, M.A.K. 1985. Systemic background. In Systemic Perspectives on Discourse, vol. 1, ed. J.D. Benson and W. Greaves. Norwood: Ablex.

Halliday, M.A.K. 2003. On Language and Linguistics. In Volume 3 of Collected Works of M.A.K. Halliday. 'New ways of meaning: the challenge to applied linguistics', ed. Jonathan Webster. London: Edward Arnold. First published in Journal of Applied Linguistics 6 (Ninth World Congress of Applied Linguistics Special Issue), 1990, pp.7-36.

Halliday, M.A.K., and Christian M.I.M. Matthiessen. 1999. Construing Experience through Meaning: a Language-based Approach to Cognition. London: Cassell.

Halliday M.A.K., and Matthiessen Christian MIM. 2004. An Introduction to Functional Grammar, Thirdth ed. London: Edward Arnold.

Hartmann, John F. 1994. Pronominal Strategies in Tai Dam Poetic Discourse. In K. L. Adam and T.J. Hudak (eds.), Paper from the Second Annual Meetings of the Southeast Asian Linguistics Society. Arizona State University. 187-199.

Janthasoon, Sukanya. 1995. Local Wisdom and Its Enculturation: A Study of 'Sen Ruen Rite' of Lao Song in Phisanulok Province. M.A. Thesis, Silpakorn University. (in Thai).

Jiranuntanaporn, Suphattra, Unchalee Singnoi, and Siriporn Maneechuket. 2003. A Grammatical System of Thai Song in Phisanulok Province. Phitsanulok: Naresuan University (in Thai).

Klinubon, Suthawee. 2009. Mu Ban Thalo MU 8 Tambon Yangyong, Amphoe Thayang, Phetchaburi Province. Special Study on Folklore. Nakhon Pathom: Silpakorn University. in Thai.

Kongyimlamai, Panthip. 2003. Sain-Huen Traditional Ceremony as the Way of Life of Lao Songs: a Case Study of Nong Prong Subdistrict, Khao Yoi District, Phetchaburi Province. M.A. Thesis, Mahidol University. (in Thai).

Lebar, Frank M., Gerald C. Hickey, and John K. Musgrave. 1964. Ethnic Groups of Mainland Southeast Asia. New Haven: Human Relations Area Files Press.

Maneewong, Orapin. 1987. A Comparative Phonological Study of Lao Song in Phetchaburi and Nakhon Pathom Provinces. M.A. Thesis. Mahidol University.

Martin, James R. 1992. English Text: System and Structure. Amsterdam: John Benjamins.

Martin, James R., Christian M.I.M. Matthiessen, and Clare Painter. 2010. Deploying Functional Grammar. Beijing: The Commercial Press.

Martin, James R., and David Rose. 2008. Procedures and Procedural Recounts. Genre Relations: Mapping Culture. London: Equinox.

Matthiessen, Christian M.I.M. 1995. Lexicogrammatical Cartography: English Systems. Tokyo: International Language Sciences Publishers.

Matthiessen, Christian M.I.M. 1999. The System of Transitivity: an Exploratory Study of Text-based Profiles. Functions of Language 6(1): 1-51.

Matthiessen, Christian M.I.M., and Christopher Nesbitt. 1996. On the idea of theory-neutral descriptions. In Functional Descriptions: Theory in Practice, ed. Carmel Cloran, David Butt, and Ruqaiya Hasan, 39-85. Amsterdam: John Benjamins.

Matthiessen, Christian M.I.M., and A.K. Halliday Michael. 2010. Systemic Functional Grammar: A First Step into the Theory. Beijing: Higher Education Press.

Muanjancheoy, Ranu. 1999. World View of Ethnic Groups in Thailand: Spiritual Beliefs of Thai Song. Nakhon Pathom: Research Institute of Language and Culture for Rural Development (in Thai).

Osiri, Sirinda. 2013. A Discourse Analysis of Tai Dam Ritual Procedural Texts. M.A. Thesis. Mahidol University

Panalai, Phramaha Prachak. 2008. The Transmission of Folk Customs, Beliefs and Ritual Wisdom by 'Mor Sen Ruen' among the Thai Song Dam Community of Muang District in Chumporn Province. M.A. Thesis, Silpakorn University. (in Thai).

Panich, Anchana. 1994. Final Particles in Lao Song. M.A. Thesis. Mahidol University. (in Thai).

Patpong, Pattama. 2010. "Voices from "Little Languages" in Thailand and Systemic Functional Linguistics Contributions to Minority Language Studies. In Proceedings of the $35^{\text {th }}$ International Systemic Functional Linguistics Congress on "Voice around the World", ed. Christian Matthiessen, Wu Canzhong, and Herke-Couchman Maria. Sydney: Macquarie University.

Patpong, Pattama. 2011a. A Generic Structure Potential Analysis of Thai Song Dam Folktales. Thailand: A paper presented at the 21st Annual Conference of Southeast Asian LinguisticsSociety at Kasetsart University.

Patpong, Pattama. 2011b. Textual Resources of Thai Song Dam Folktales. Bangkok: A paper presented at The 11th International Conference on Thai Studies at the Siam City Hotel.

Patpong, Pattama. 2013. Thematic Progression of Thai Song Dam Folktales. Journal of the Southeast Asian Linguistics Society (JSEALS) 6: 189-215.

Phosan, Apinwat. 2009. Essences of Lao Song Beliefs and Rituals. Mahasarakham: Apichat Kan Prim.

Pittphat, Sumitr. 1978. Long Song: Research Report. Bangkok: Thammasart University. 
Pittphat, Sumitr. 2002. Religious and Tai Dam Beliefs in Sipsongchutai, Vietnam. Bangkok: Thammasart University.

Premsrirat, Suwailai. 2007. Endangered Languages of Thailand. International Journal of the Sociology of Language 186: 75-93.

Premsrirat, Suwailai, et al. 2004. Ethnolinguistic maps of Thailand. Bangkok: Khurutsaphaa (in Thai).

Schliesinger, Joachim. 2001. Tai groups of Thailand 2: Profile of the Existing Groups. Bangkok: White Lotus Co., Ltd.

Subsook, Relai, Yodkaew Suksaman, and Settawat Rachadapan. 1980. The Verbal Folk Literature of Thai Song Dam Amphoe Khaoyoy, Phetchaburi Province. Phetchaburi: Faculty of Humanities and Social Sciences (in Thai).

Thavorn, Sopita. 2013. Phonological Variation and Change in Tai Dam. M.A. Thesis. Mahidol University. (in Thai).

Thompson, Geoff. 2014. Introducing Functional Grammar, 3rd ed. United Kingdom: Routledge.

Trong, Cam. 2007. The Thai Ethnic Community in Vietnam. The Gioi Publishers.

Udomwej, Manu. 2004. History of black Tai in Thailand. Phetchaburi: Faculty of Humanities And Social Sciences. Phetchaburi Rajabhat University. (in Thai).

Wadkeaw, Mayuree. 1978. The Study of Social Structure of Lao Song. M.A. Thesis (Social Development). Kasetsart University. (in Thai).

Wattanaprasert, Kantima, and Suwattana Liamprasert. 1988. The Phonology of Lao Dialects in Thachin River Basin. Nakhon Pathom: Silpakorn University Press (in Thai).

Yensamut, Panida 1981. Words and Meanings of Lao Song. M.A. Thesis. Silpakorn University. (in Thai).

Yimrewat, Pattiya. 2001. History of Sip Song Chu Tai. Bangkok: Sangsan Publishing (In collaboration with Thailand Research Fund and Chulalongkorn University). (in Thai).

Yooyen, Penwipa. 2013. Tone Variation of Thai Song by Age Group in Ratchaburi Province. M.A. Thesis. Mahidol University. (in Thai).

Submit your manuscript to a SpringerOpen ${ }^{\circ}$ journal and benefit from:

- Convenient online submission

Rigorous peer review

- Immediate publication on acceptance

- Open access: articles freely available online

- High visibility within the field

- Retaining the copyright to your article

Submit your next manuscript at $\boldsymbol{\nabla}$ springeropen.com 